\title{
PALEO
}

Revue d'archéologie préhistorique

$26 \mid 2015$

Varia

\section{New hominin remains from the site of Regourdou (Montignac-sur-Vézère, Dordogne, France)}

Nouveaux restes humains provenant du gisement de Regourdou (Montignac-surVézère, Dordogne, France)

Bruno Maureille, Asier Gómez-Olivencia, Christine Couture-Veschambre, Stéphane Madelaine and Trenton Holliday

\section{OpenEdition}

\section{Journals}

Electronic version

URL: http://journals.openedition.org/paleo/3028

DOI: $10.4000 /$ paleo.3028

ISSN: 2101-0420

\section{Publisher}

SAMRA

Printed version

Date of publication: 1 December 2015

Number of pages: 117-138

ISSN: 1145-3370

\section{Electronic reference}

Bruno Maureille, Asier Gómez-Olivencia, Christine Couture-Veschambre, Stéphane Madelaine and Trenton Holliday, « New hominin remains from the site of Regourdou (Montignac-sur-Vézère,

Dordogne, France) », PALEO [Online], 26 | 2015, Online since 26 April 2016, connection on 07 July 2020 URL : http://journals.openedition.org/paleo/3028 ; DOI : https://doi.org/10.4000/paleo.3028

This text was automatically generated on 7 July 2020 .

\section{(c) $(1)$}

PALEO est mis à disposition selon les termes de la licence Creative Commons Attribution - Pas d'Utilisation Commerciale - Pas de Modification 4.0 International. 


\section{New hominin remains from the site of Regourdou (Montignac-sur- Vézère, Dordogne, France)}

Nouveaux restes humains provenant du gisement de Regourdou (Montignac-surVézère, Dordogne, France)

Bruno Maureille, Asier Gómez-Olivencia, Christine Couture-Veschambre, Stéphane Madelaine and Trenton Holliday

We wish to thank the National Museum of Prehistory and its director, Jean-Jacques Cleyet-Merle, and the Museum of Art and Archaeology of the Périgord and its curator, Veronique MerlinAnglade for their authorizations to study the fossil material and the collections kept in their institutions. We express our gratitude to Michèle Constant for the loan of part of the collections of the Regourdou site she keeps in her site museum. We are thanking Philippe Jugie for the photographs of the original Regourdou 1 bones and Eugene Bonifay for the information he gave us. This research was made possible thanks to: the project Transitions agreement 20051403003AB of the Aquitaine region, in Bordeaux LabEx Archaeological Sciences, a program funded by the ANR - $n{ }^{\circ}$ ANR-10-LabX-52 - NEMO project, the project CGL2012-38434-C03-01 of the Ministerio de Economía y Competitividad (Spain) and investigation group IT834-13 of the Eusko Jaurlaritza / Gobierno Vasco, to the Louisiana Board of Regents LEQSF (2015-18)-RD-A-22. The micro-CT of part of the Regourdou material was made possible by Leakey Foundation scholarship thanks to the generous donation done by Gordon Getty and Cole Thompson.

\section{Introduction}

1 The site of Regourdou is located near the town of Montignac-sur-Vézère (Dordogne, France; fig. 1), on the left bank of the Vézère valley, at the top of the hill where Lascaux cave also opens. The human remains discovered there are part of the history of prehistoric sciences in the Southwest of France at the beginning of the second half of the twentieth century, namely (i) an accidental unearthing in 1957 under highly destructive conditions (Piveteau 1959), (ii) discoveries during difficult scheduled 
excavations from 1961 to 1964 under the direction of Eugène Bonifay (Bonifay, 1964, 1965, 2002; Bonifay and Vandermeersch 1962; Bonifay et al. 2007; Piveteau 1963) and (iii) discoveries in the mid-2000s of new human remains in the faunal collection acquired by the National Museum of Prehistory (NMP) (Madelaine et al. 2008; fig 2).

2 The present contribution represents an update of the inventory of the human remains coming from, or supposed to come from (see below), this site. No fewer than 59 new bone fragments or complete bones were found; they will be briefly described below.

3 It is also interesting to note that according to various previous researchers (Piveteau, 1959, 1963, 1964, 1966; Trinkaus 1975; Vandermeersch and Trinkaus 1995), the presence of two Neanderthal individuals has been assumed on the basis of (mainly) an articular asymmetry between the right talus (marked "Regourdou G3 63") and the right calcaneus (marked "Reg 35 ou R = G1 35 ") attributed to Regourdou 1. Both were unearthed during the excavations directed by E. Bonifay. This hypothesis seems all the more relevant as the articular symmetry of these two bones is very good in modern Humans (Villena y Mota 1997). In the following contribution, we present two new unmarked calcanei: a right one and a left one, leading to a total of three bones of this type in the collections of the site. Therefore, the new discoveries confirm the presence of at least two individuals in Regourdou.

\section{1 - New human remains attributed to Regourdou 1}

4 For simplicity, in the remainder of this publication, for the vertebrae and ribs, we have retained below the inventory numbers proposed by Gómez-Olivencia et al. (2013a, 2013b).

\section{Vertebral fragments}

5 All the new elements have been attributed to Regourdou 1; some have been reassembled and are presented with the skeleton in the Musée d'Art et d'Archéologie du Périgord (MAAP). Moreover, we have published (Gómez-Olivencia et al. Ibid) a complete inventory and metric analysis of these vertebrae.

6 First cervical vertebra (V\#ai+V\#ay; NMP collection; fig. 3). The atlas is now represented by the anterior and posterolateral right two-thirds of the complete bone. Two bone fragments (including the anterior arch) have been refitted. The anterior tubercle is preserved as well as the articular facets and the right transverse lamina. Again, fresh breaks are visible at the ends of the existing parts.

7 Fragment of neural arch of the $6^{\text {th }}$ cervical vertebra (V\#ah; NMP collection; fig. 3 ). It comes from the same batch of remains that those among which coxal fragments and some elements of the trunk were found. It is marked "Reg. $n^{\circ} 37^{\prime}$, which ensures that it was unearthed during the 1957 rescue. It is represented by the right and left vertebral laminae and half of the spinous process of a cervical vertebra. Its maximum dimensions are $27 \mathrm{~mm}$ dorsoventrally and $28.3 \mathrm{~mm}$ mediolaterally. This is more specifically the $6^{\text {th }}$ cervical vertebra identified by Piveteau (1966) since this new fragment refits perfectly with the preserved portion of this vertebra, known since 1957.

Distal extremity of the spinous process of the $7^{\text {th }}$ cervical vertebra (V\#al; NMP collection; fig. 3). This unmarked part is an extremity of the spinous process of a cervical vertebra. It refits very well with the preserved part of the $7^{\text {th }}$ cervical vertebra of Regourdou 1 
(Gomez-Olivencia et al. 2013a) that was identified by Piveteau (1966 - p. 191, fig. 50) as the first thoracic vertebra.

Left fragment of neural arch of the first thoracic vertebra (V\#ap; NMP collection; fig. 4). This part is marked "entre 51 et 47» ("between 51 and 47") and preserves part of the pedicle, the transverse process and the superior articular facet. It has at least one area of fresh breakage, but the marking ensures that this fragment was found in this state during the rescue excavation.

10 Fragment of right lamina of the first thoracic vertebra (V\#ba; NMP collection; fig. 4). This part is not marked and is roughly quadrangular in shape. It is light in colour and corresponds to a right lamina fragment with the inferior articular surface. The articular congruence with the second thoracic vertebra allows us to assume that we are dealing with a fragment of the first thoracic vertebra.

11 Neural arch of the $7^{\text {th }}$ thoracic vertebra (V\#ak; NMP collection; fig. 4). It is the posterior part of the vertebral left and right laminae (less well preserved) with the preserved inferior articular facets of a thoracic vertebra. The spinous process is broken at the root. This fragment is not marked but comes from a bag identified as "bone fragments without location = Sep?." It refits with another fragment and corresponds to part of the $7^{\text {th }}$ thoracic vertebra known by a significant part of its body (Gomez-Olivencia et al. 2013a), an object marked "Reg D." This body could match the third thoracic vertebra mentioned (but not described) by Piveteau (1966 - p.172).

12 Superior articular process of the $7^{\text {th }}$ thoracic vertebra (V\#an; NMP collection; fig. 4). This small unmarked quadrangular fragment corresponds to the left pedicle and the superior left articular facet. It refits with a fragment from the original collection.

13 Superior articular facet of the $10^{\text {th }}$ thoracic vertebra (V\#av; NMP collection; fig. 4). This small fragment, which is not marked, corresponds to an articular facet. It refits with a neural arch fragment from the original collection.

14 Neural arch of the $11^{\text {th }}$ thoracic vertebra (V\#aj; MNP collection; fig. 4). These are the right and left vertebral laminae with well-preserved inferior articular facets of a thoracic vertebra. Unfortunately the spinous process is broken at the root. This fragment is not marked. It refits with a vertebra known since 1957. The latter must have been considered by Piveteau as a thoracic vertebra "placed towards the end of the series" (Piveteau 1966, p. 191). We are assuming that this is the $11^{\text {th }}$ (Gomez-Olivencia et al. 2013).

15 Fragment of neural arch of the $12^{\text {th }}$ thoracic vertebra (V\#aq+V\#ar; NMP collection; fig. 4). This is: (i) the right vertebral lamina with the right superior articular facet, (ii) the right pedicle and (iii) a portion of the right inferior articular facet and the root of the spinous process of a thoracic vertebra. This element is represented by two fragments that refit together and that are marked "Regourd Sep. $1957 \mathrm{n}^{\circ} 52$ "(V\#ar) and « 58 axe 32 poteau " ("58 axis 32 post") (V\#aq). Therefore, they were found in the rescue excavation of the human deposit. For now, the fragment represented by $\mathrm{V} \#$ ar refitted with $\mathrm{V}$ \#aq does not refit with the body of one of the thoracic vertebrae found with the skeleton kept at the MAAP. But the morphology of the fragment and the position of the articular facet with the head of the rib relative to the root of the transverse process lead us to assume that it is a fragment of the $12^{\text {th }}$ thoracic vertebra.

16 Left transverse process of thoracic vertebra ( $\mathrm{V \# au}$; NMP collection; fig. 5a). The object is whole and shows slight erosions. It is marked "Reg. $\mathrm{N}^{\circ} 51$," which ensures that it was 
unearthed in 1957. Its root is broken and we cannot be certain of the old age of the break.

Left transverse process of thoracic vertebra ( $\mathrm{V \# am;} \mathrm{NMP} \mathrm{collection;} \mathrm{fig.} 5 \mathrm{~b})$. The object is less complete than the previous one. It is not marked. Its root is broken (old fracture?). Transverse process of thoracic vertebra (V\#ao; NMP collection; fig. $5 \mathrm{c}$ ). This small quadrangular fragment is not marked. It has a small portion of articular facet with the head of the rib. It is with certainty a fragment of right transverse process of a thoracic vertebra.

19 Superior articular process of a thoracic vertebra (V\#as; NMP collection; fig. $5 \mathrm{~d}$ ). This small fragment is marked "58 axe 32 poteau" ("58 axis 32 post") and thus was unearthed during the 1957 rescue excavation. It corresponds to a quadrangular lamina fragment, from a thoracic vertebra, with the superior right articular facet.

Spinous process fragment of a lumbar vertebra (V\#ax; NMP collection; fig. 6). This object is marked" $n^{\circ} 47,48,49$ " and was unearthed in 1957. It is a fragment of spinous process of lumbar vertebra with fresh breaks.

21 Root of the spinous process of a lumbar vertebra (V\#at; NMP collection; fig. 6). This small fragment is marked "Reg. No. 51." It was discovered in 1957. It is probably the root of the spinous process of a lumbar vertebra. The short craniocaudal height of this root would rather plead for a fourth or fifth lumbar vertebra.

Fragment of thoracic or lumbar vertebral body (V\#aw; NMP collection; fig. 6). This small fragment is marked "Reg. No. 47 "and was unearthed in 1957. Its small size does not allow its anatomical determination.

Fragment of the first coccygeal vertebra (V\#az; NMP collection; fig. 6). This small fragment is not marked. It represents the upper surface of the vertebra. 
Figure 1 - Location of the Regourdou site.

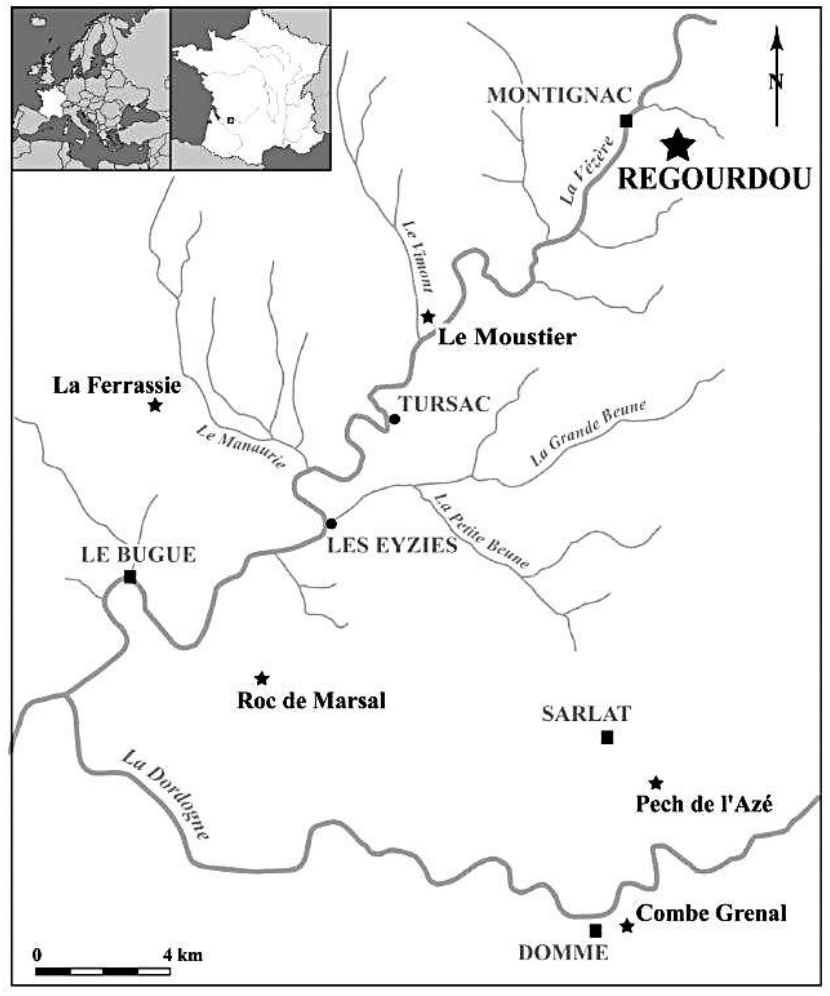

Figure 2 - The Regourdou 1 skeleton as presented at the Musée d'Art et d'Archéologie du Périgord after 2008. Picture Bernard Dupuy, MAAP collections, City of Périgueux.

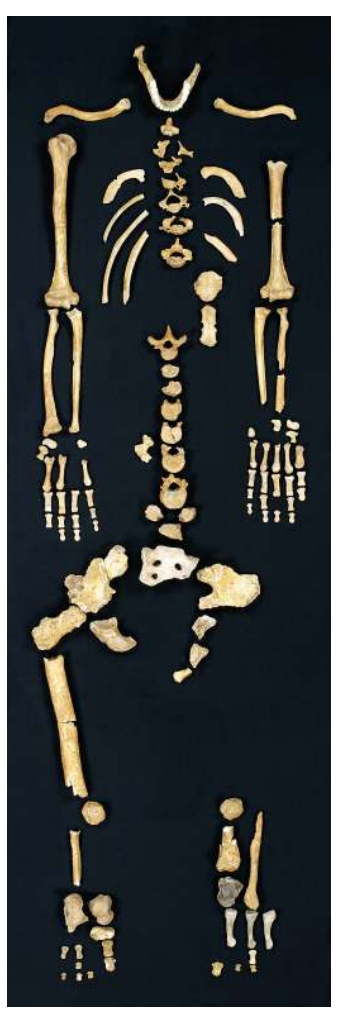


Figure 3 - Cervical vertebrae: atlas (V\#ai+V\#ay), neural arch of the 6 th, tip of the spinous process of the 7 th.

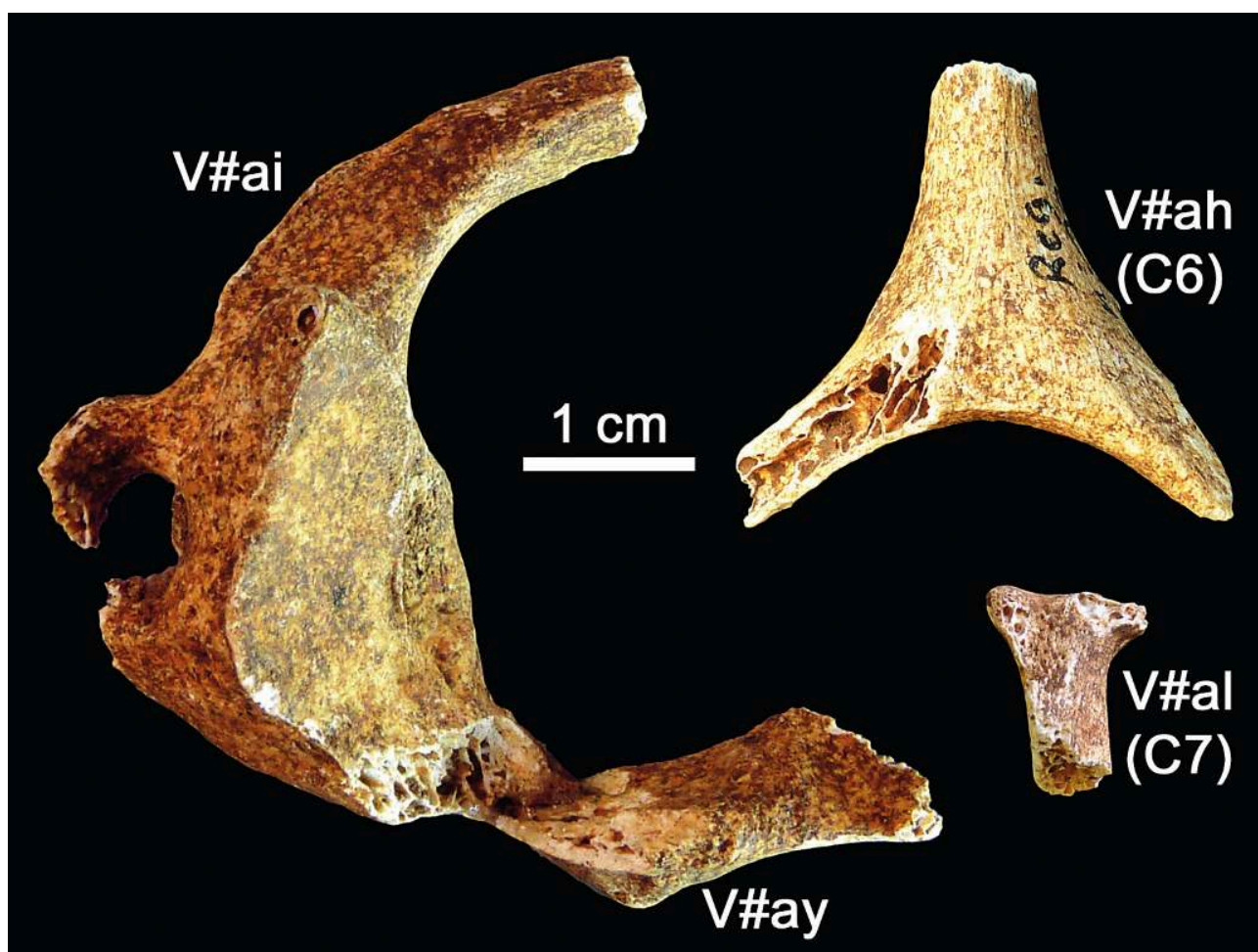

Figure 4 - Principal thoracic vertebral remains. Fragment of left side of neural arch of 1 st thoracic vertebra (V\#ap). a: posterior view,b: superior view ; fragment of right lamina of 1 st thoracic vertebra (V\#ba), c: posterior view, $d$ : anterior view; neural arch of 7 th thoracic vertebra (V\#ak), e: posterior view, f: anterior view ; left superior articular process of 7 th thoracic vertebra (V\#an), g: lateral view, h: medial view; superior articular surface of 10 th thoracic vertebra (V\#av and i), neural arch of 11 th thoracic vertebra (V\#aj and j), posterior view; fragment of neural arch of 12th thoracic vertebra (V\#aq+V\#ar), k: posterior view, l: medial view.

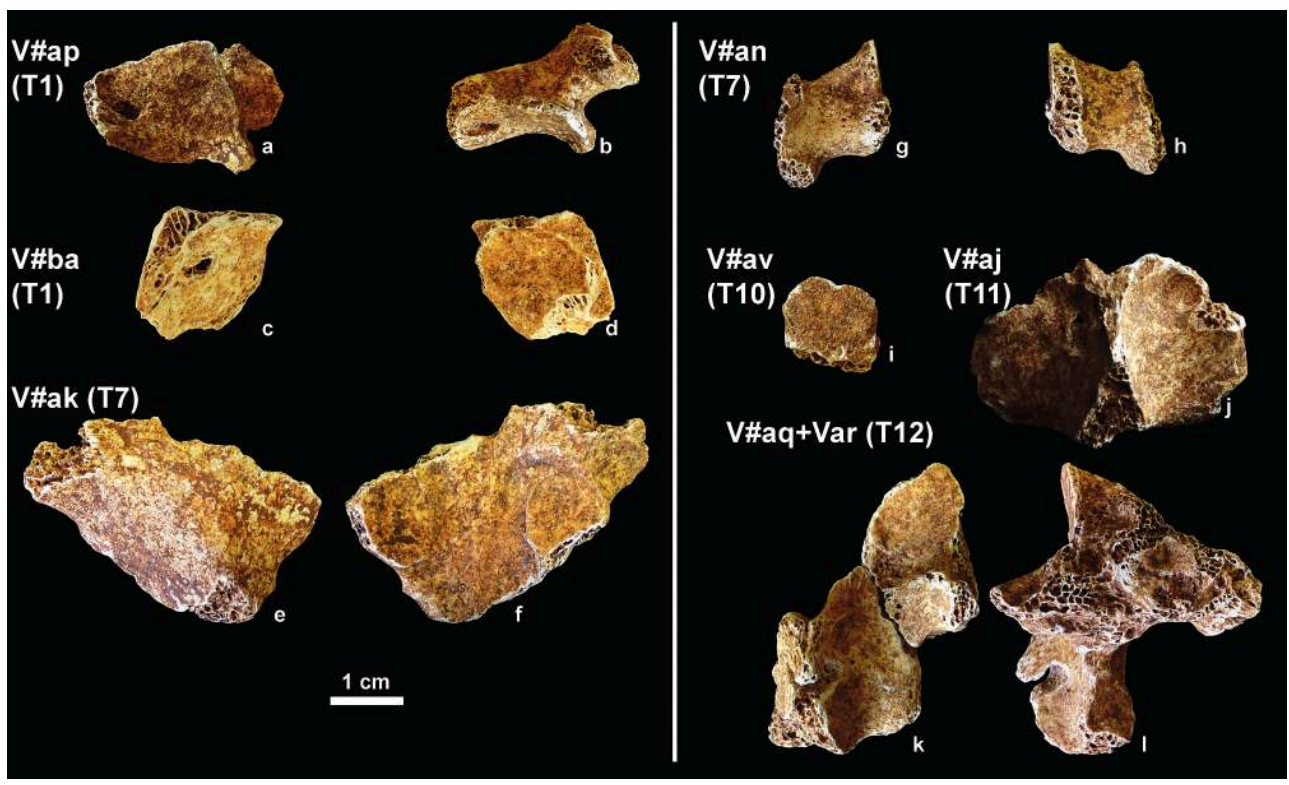


Figure 5 - Additional remains of thoracic vertebrae. a: left tranverse process, b: left transverse process, c: transverse process,d: superior articular process.

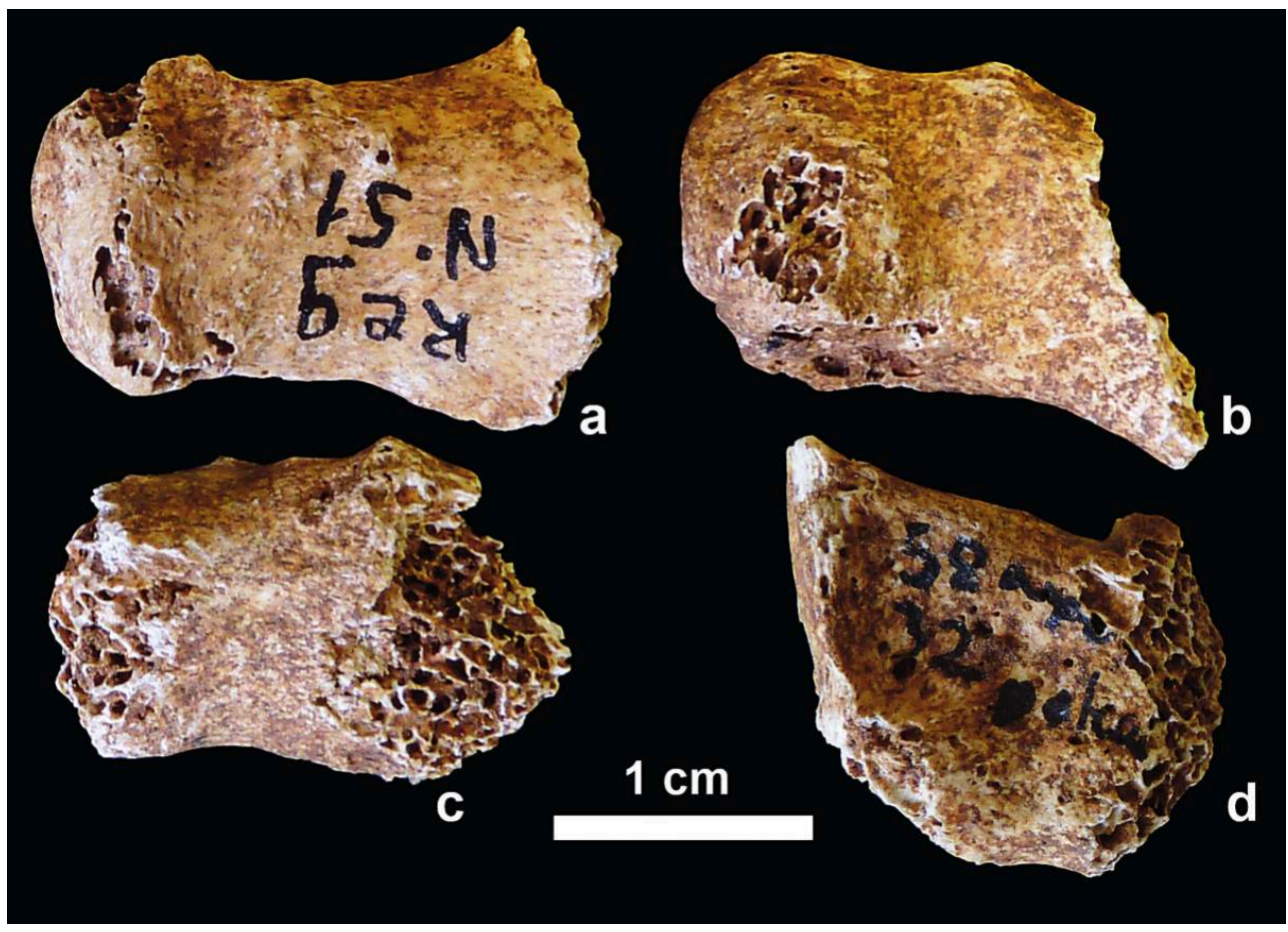

\section{Rib fragments}

Some have been identified by BM and SM during the winter 2008. Then AGO increased this inventory by isolating many other fragments. He also looked for refits and was thus able to specify the number and side of several ribs. All of these new remains are illustrated in the synthetic inventory of figure 7 and on figures 8, 9 and 10. 
Figure 6 - Additional vertebral remains. V\#ax: spinous process of a lumbar vertebra, V\#at: root of the spinous process of a lumbar vertebra, V\#aw: fragment of a lumbar or thoracic vertebra body, V\#az: body of the first coccygeal vertebra.

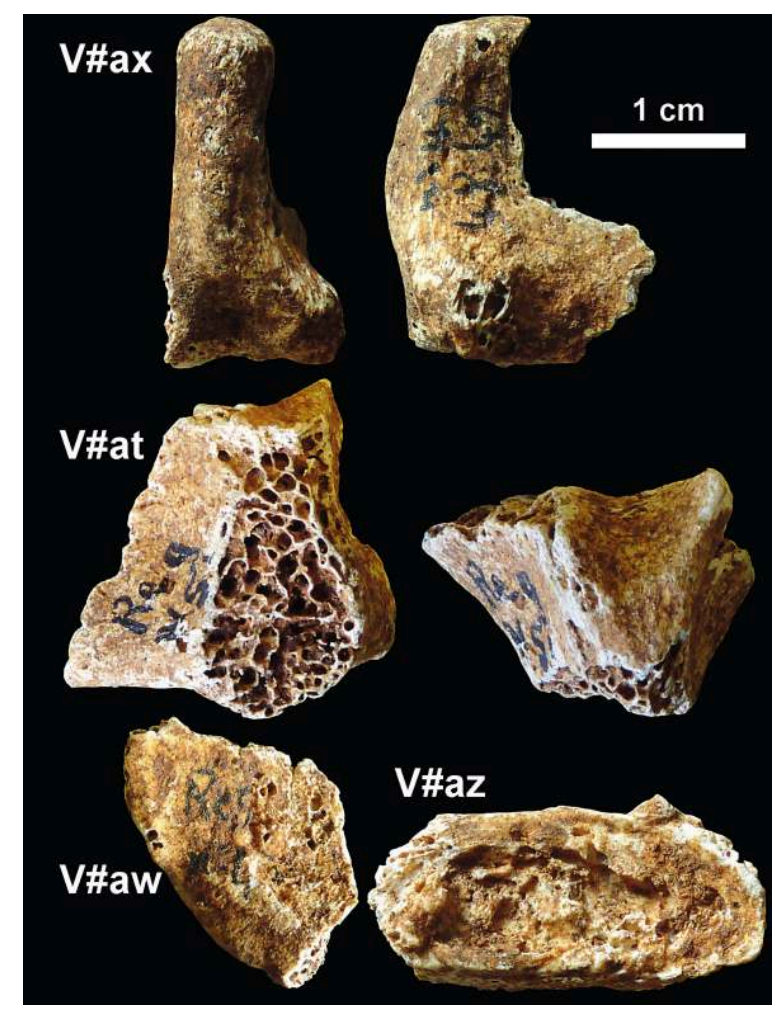

\section{Ribs for which a number is proposed}

substantial part of the body of a low number left rib. It is marked "Regourdou Sep. 1957 sur le bloc où était la p. droite de la md" ("Regourdou Sep.1957 on the bloc on which the right p. of the md was"). It consists of several small fragments that refit and the breakages are fresh at both ends. This piece also refits with other fragments of a $2^{\text {nd }}$ left rib to form a nearly complete bone except for the sternal end.

Third left rib (R\#s; NMP collection; fig. 9). This fragment, $42 \mathrm{~mm}$ long, refits with the vertebral end of the $3^{\text {rd }}$ left rib of the original collection and its morphology is consistent with that number. It is marked "Reg Sep. 195 No. 18." The "7" of 1957 is absent due to recent erosion. The object shows fresh fractures on both sides.

29 Fourth right rib (R\#ab+R\#ac; NMP collection; fig. 9). These are two refitting rib fragments. The first one (R\#ab) marked "No. 47-48-49" shows half of the articular facet 
of the tubercle and a part of the body before the angle of the latter. The second fragment ( $\mathrm{R \# aC)}$ is identified "Reg Sept 1957 No. 47-48-49." This is the entire angle of the rib as well as a few $\mathrm{cm}$ of the body. We associate these two fragments to the $4^{\text {th }}$ right rib. Both ends show fresh breaks.

(R\#an+R\#am; NMP collection; fig. 9). This $87 \mathrm{~mm}$ long fragment, consisting of two unmarked pieces, shows part of the body of a right rib. Its curvature and morphology indicate that it would be the $4^{\text {th }}$ rib.

31 (R\#z; NMP collection; fig. 9). This is an unmarked $69 \mathrm{~mm}$ long fragment, consisting of two pieces (a very small one at one end), which represents part of the body up to the sternal end of the rib. It refits with R\#an+R\#am but the small surface between the two fragments would make the reconstructed body too fragile.

Sixth(?) right rib (R\#ap+R\#aq; NMP collection; fig. 9). This $53 \mathrm{~mm}$ long fragment is formed by two pieces. The vertebral end (R\#ap) is marked "sous os 47 " ('under bone 47") and the sternal end (R\#aq) is marked "No. 4748 49." It represents a part of the angle of a right rib, of medium number, possibly a $6^{\text {th }}$ rib.

Seventh (?) right rib ( $\mathrm{R} A \mathrm{ad}+\mathrm{R} \# \mathrm{ah}+\mathrm{R} \#$; NMP collection; fig. 9). This fragment of a rib body is $148 \mathrm{~mm}$ long. It is made of four pieces. The most vertebral ( $\mathrm{R \# ad)} \mathrm{is} \mathrm{not} \mathrm{marked.} \mathrm{The}$ following (R\#ah) is marked "Reg No. 47" and the last two (R\#ak) are marked "No. 4748 49 ". We consider we are in the presence of a part of right rib of intermediate number (5 to 9), possibly a $7^{\text {th }}$ rib with fresh breaks on both ends. Note that the most sternal part of the rib shows a particular swelling (fig. 10). The micro-CT recording allows underlining the existence of an abnormal porosity in the compact portion of the external side of the body.

34 A recent review has also allowed us to refit the R\#af fragment (NMP collection; fig. 8) at the sternal end of the $7^{\text {th }}$ right rib. R\#af is $44 \mathrm{~mm}$ long. It is marked "Regourdou sép. 1957 groupe 55." This object tells us that, during the rescue excavation of October 1957, some objects were collected as batches, information one could have guessed when reading the field notes written by François Bordes. This explains why some bones have the same numbers.

Ninth (?) left rib (R\#aa; NMP collection; fig. 9). This $54.5 \mathrm{~mm}$ long fragment identified "Regourdou sous le femur" ("Regourdou under the femur") would potentially represent the angle of the $9^{\text {th }}$ left rib whose large cranio-caudal diameter at the posterior angle is close to that of Kebara 2.

Eleventh right rib (R\#w; NMP collection; fig. 8). This fragment is not marked. It measures $21.9 \mathrm{~mm}$ long and represents the sternal end of the $11^{\text {th }}$ right rib. It refits together with

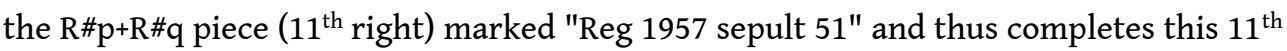
rib. Therefore this group makes a third nearly-whole rib of this individual.

Twelfth right rib (R\#u; NMP collection; fig. 8). This fragment of body rib measures $45 \mathrm{~mm}$ long. It is marked "Regourdou Sept 1957 No. 52". There is at least one fresh break at the level of the vertebral end. Depending on the low cranio-caudal height of the body in relation to its thickness, we assume we have a $12^{\text {th }}$ right rib. This robustness of the $12^{\text {th }}$ Neanderthal rib was indeed underscored by Franciscus and Churchill (2002) on Shanidar 3 and is also observable on La Ferrassie 1 (AGO, pers. obs.). 
Figure 7 - Schema, likely position of new costal remains.

\section{Côté gauche}

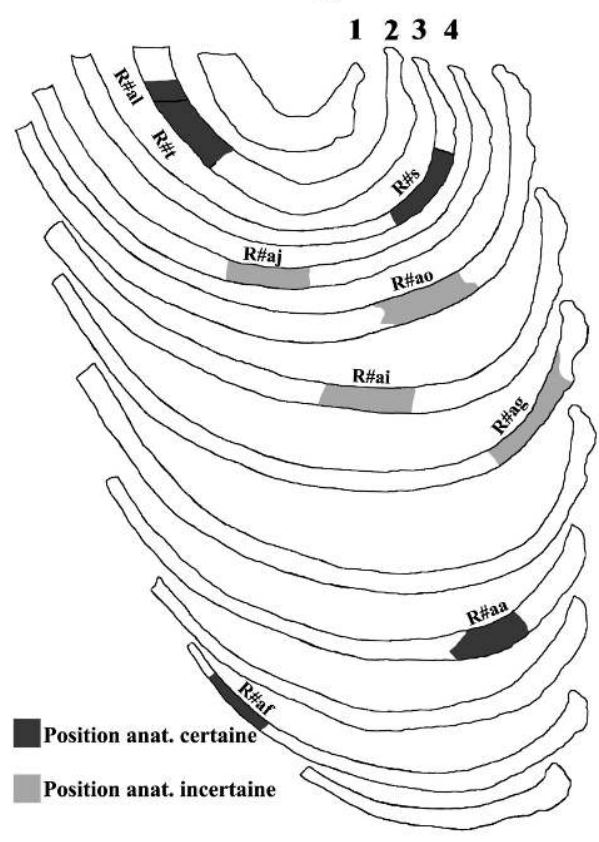

\section{Côté droit}

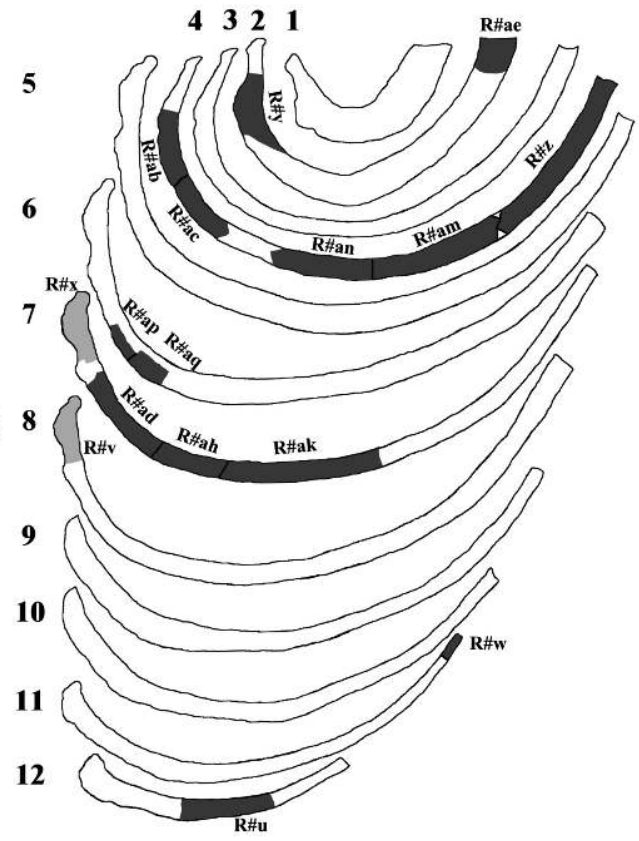

Figure 8 - Diverse rib fragments. R\#t+R\#a: right 2nd rib, R\#ae: right 2nd rib, R\#y: right 2nd rib, R\#u: right 12th rib, R\#af: left 11 th rib, R\#w: right 11 th rib, R\#x right 5th-10th rib, R\#v right 5th-10th rib.

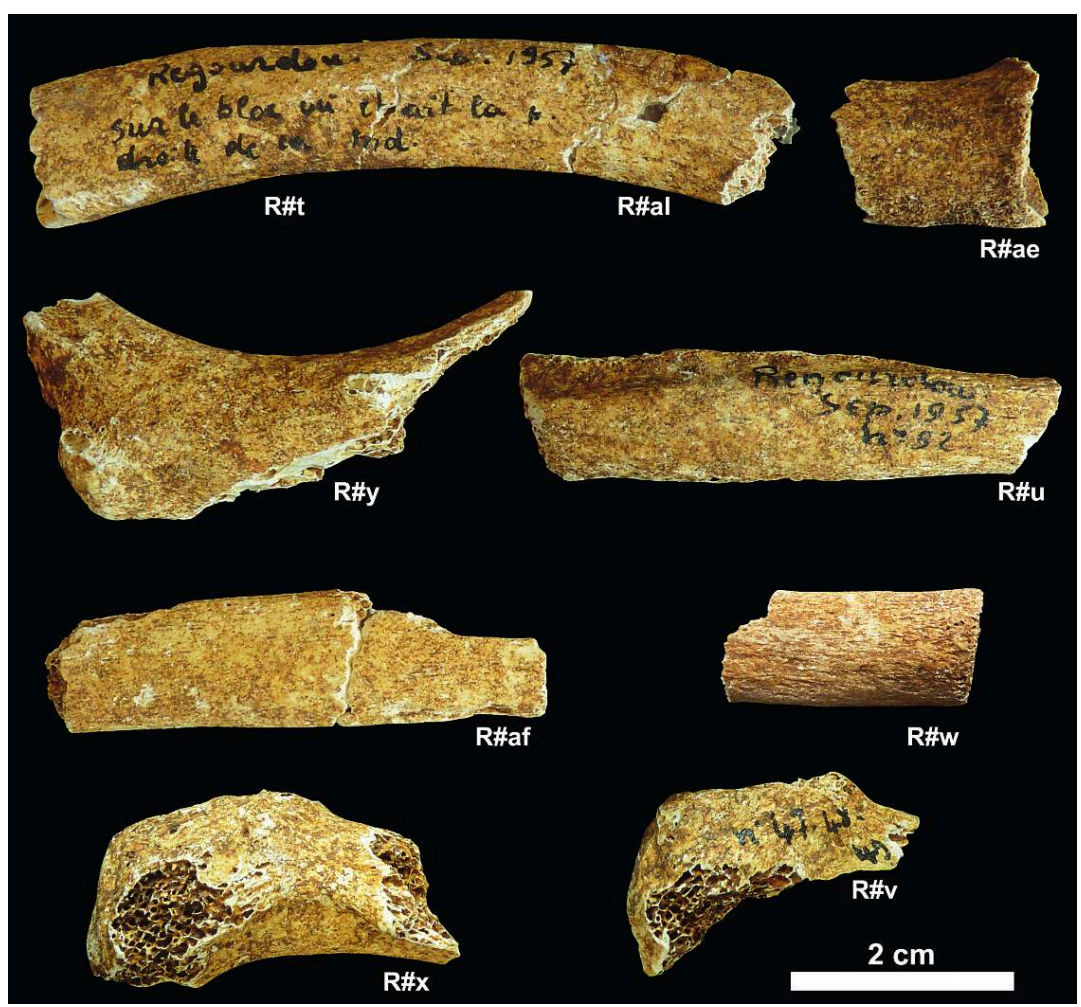




\section{Ribs with uncertain number} right rib whose number can be from the $4^{\text {th }}$ to the $7^{\text {th }}$ rib. This fragment is $32 \mathrm{~mm}$ long. It is not marked. The articular facet with the body of the vertebra does not show any pathology. The fracture at the level of the tubercle is fresh.

Right rib (R\#v; NMP collection; fig. 8). This fragment of a head, $27 \mathrm{~mm}$ long, belongs to a right rib that can be from the $5^{\text {th }}$ to the $10^{\text {th }}$ rib. It is less complete than the previous one. It is marked "No. 474849 " and unfortunately has a fresh break at the neck.

$5^{\text {th }}$ or $6^{\text {th }}$ left rib (R\#ag; NMP collection; fig. 9). This fragment is the part of the body between the articular facet (with the vertebral transverse process) and the angle of a left rib ( $5^{\text {th }}$ or $\left.6^{\text {th }}\right)$. It is $45 \mathrm{~mm}$ long and is not marked.

41 Left rib (R\#ao; NMP collection; fig. 9). It is a portion of the body (55 $\mathrm{mm}$ long) from a left

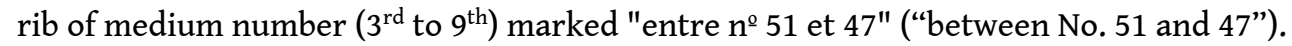

Left rib (?) (R\#ai; NMP collection; fig. 9). This fragment of a rib body is $41 \mathrm{~mm}$ long. It is marked "Reg. Sep. 1957 derrière la md" ("Reg. Sep. 1957 behind the md"). This is, we believe, a piece of left rib (?) of intermediate number ( $3^{\text {rd }}$ to $\left.8^{\text {th }}\right)$. It shows fresh breaks on each side.

Indeterminate rib (R\#aj; NMP collection; fig. 9). This body rib fragment is $47.5 \mathrm{~mm}$ long. It is marked " 58 axe 32 poteau" ("58 axis 32 post"). It shows fresh breaks on each side. As the number and the side cannot be determined, we randomly positioned it at the $5^{\text {th }}$ left rib on figure 7.

Note that we have isolated 16 other fragments in the collection of the NMP (fig. 11) that could be connected to the trunk of Regourdou 1 but for which we are not yet completely sure of the human diagnosis. Two of them are marked "Reg N 51" and "entre 51 et 47" ("between 51 and 47"). 
Figure 9 - Diverse rib fragments. R\#ad+R\#ah+R\#ak: right 7th rib, R\#ap+R\#aq: right 6thrib, R\#an+R\#am+R\#z: R\#ab + R\#ac: right 4th rib, R\#s: left 3rd rib, R\#aa: left 9th rib, R\#ag: left 5th-6th rib, R\#ao: left 3rd-9th rib, R\#ai: left 3rd-8th rib, R\#aj: left 5th (?) rib.

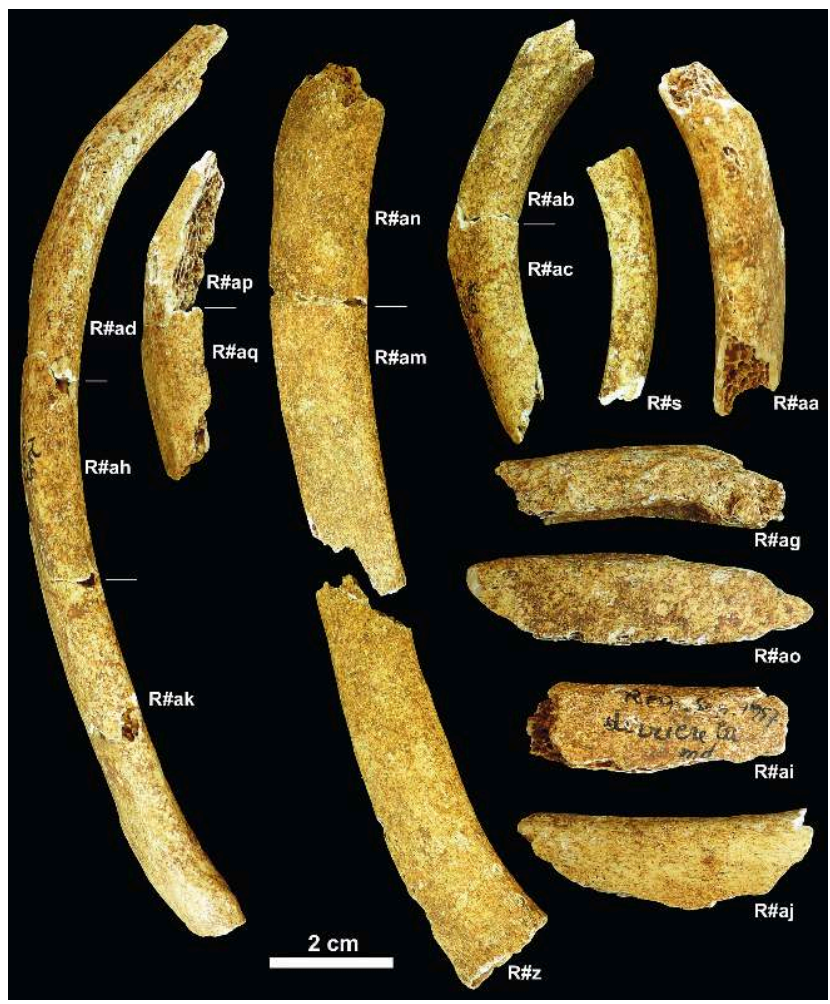

Figure 10 - Right 7th rib, cranial view (top), anterior view (middle), location and microscanned cross- sections showing pathological condition. Ext $=$ exterior, Int $=$ interior

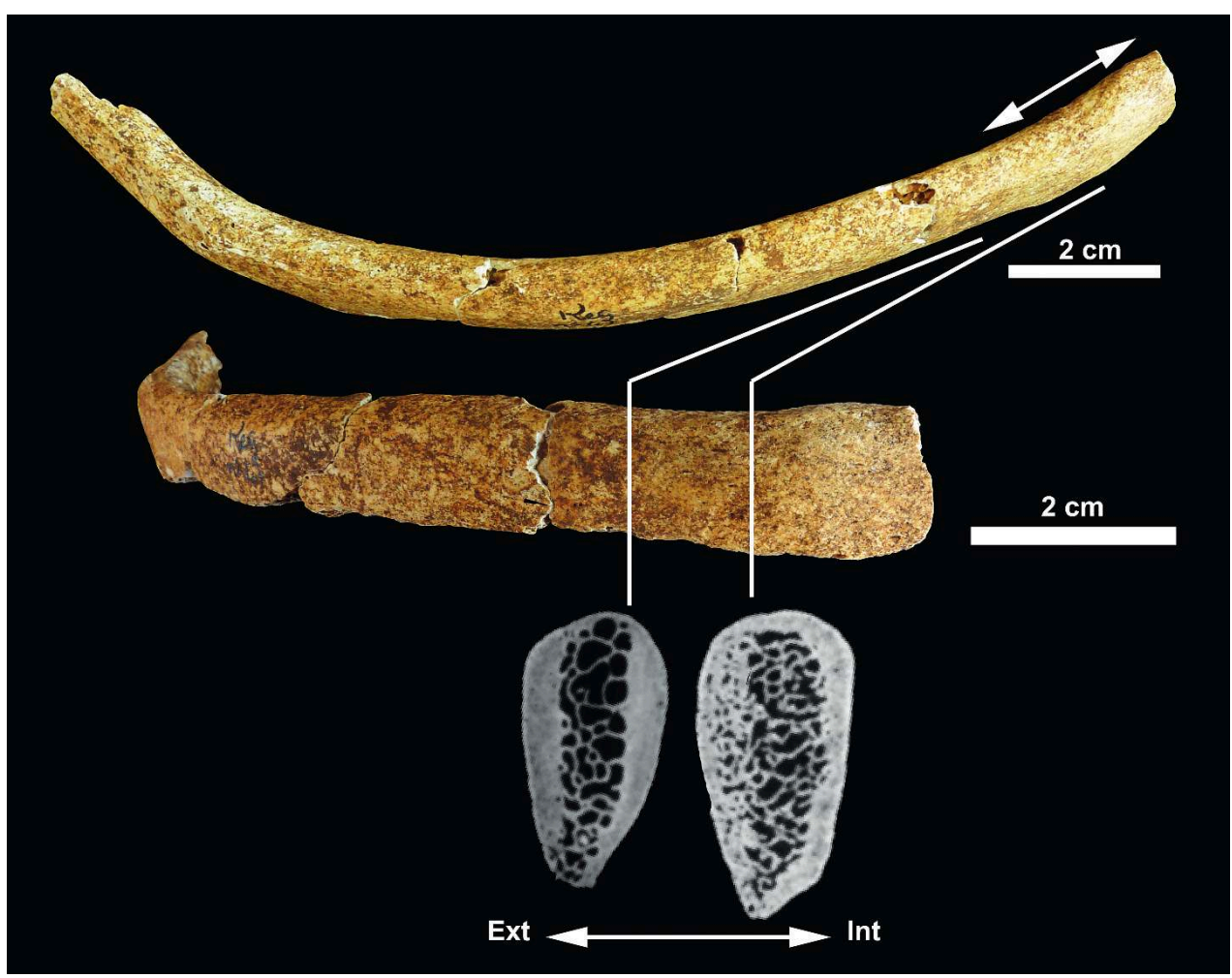




\section{Sternum (MAAP collection)} areas where the compact bone surface is eroded on the dorsal side and on part of the palmar side at the top of the articular facet with the first metacarpal. It is not marked. It is symmetrical to the left bone found in Regourdou 1 (fig. 15f). As the hand is in palmar view, the tubercle projects strongly forward and around its median plane. This trapezoid has a very similar morphology to the left one of Kebara 2 (Vandermeersch 1991).

51 In Neanderthals, the expression of this tubercle, the position of the articular facets, especially that of the scaphoid, give the trapezoid a very distinct morphology from that of current or modern humans (Musgrave 1971; Vandermeersch 1981). Finally the projection of the tubercle and that of the hamulus on the hamate allowed the formation of a very large carpal tunnel. All of these characteristics must have been accompanied by various biomechanical consequences as assumed by Niewoehner (2000).

52 Left lunate (NMP collection; fig. 15a and b). This bone is complete, unmarked. This carpal bone has characteristics that deviate from the modern morphology as it is highly 
stretched dorso-palmarily and as it shows a much more convex articular facet with the radius. This object, in association with the already known scaphoid and triquetrum, completes the first row of the carpal bones of Regourdou 1.

Left capitate (MAAP collection; fig. $15 \mathrm{c}$ and d). This bone is marked "R sous 31 ". Only the head is well preserved. The palmar face is largely incomplete. A portion of the articular facet for the $3^{\text {rd }}$ metacarpal is visible. By its morphological characteristics, this carpal bone fits better within Neanderthal variability than within the modern one.

Distal three-quarters of first right metacarpal (NMP collection; fig. 16e and g). This object is not marked. It is very well preserved except for small eroded areas on the dorsal side of the diaphysis and the dorsal and palmar sides of the articular end. The break is partly fresh only at the level of the diaphysis. The dimensions of its head $(\mathrm{ML}=17.25 \mathrm{~mm}, \mathrm{DP}=$ $11.5 \mathrm{~mm})$ are very close to that of the first left metacarpal $(\mathrm{ML}=17.25 \mathrm{~mm}, \mathrm{DP}=12.40$ $\mathrm{mm}$ ) of Regourdou 1. However, an asymmetry of part of the diaphysis between the two metacarpals can be noted. On the right one, the lateral edge seems slightly more convex, more bent and there is also a marked ridge, latero-medially oblique, developing on the palmar surface of the diaphysis, at the back of the head. The morphological differences between this fragment of metacarpal and a subcontemporary equivalent bone are notable.

Fragment of proximal extremity (or base) of a $3^{\text {rd }}$ left metacarpal (NMP collection; fig. $16 \mathrm{~m}$ and $\mathrm{n}$ ). We consider that the simplest hypothesis is that this metacarpal articular extremity fragment matches the missing part on the third left metacarpal known for Regourdou 1 with which it refits at the level of the lateral and dorsal surface (fig. 16n).

Possible proximal half of $5^{\text {th }}$ right metacarpal (MAAP collection; fig. 16i and k). The proximal articular extremity is complete. Unfortunately, the bone shows a recent fracture mid-length of the diaphysis. It is marked "Reg. Sep. 1957 sous le n'44." It shows clear morphological differences with the left $5^{\text {th }}$ metacarpal that make its taxonomic identification and its lateralization difficult. Middle phalanx of the hand (MAAP collection; fig. 16a and c). This is possibly a left phalanx. It is symmetrical to the hand phalanx discovered in 2008 (marked "F2-87 Reg") and identified as a possible right phalanx belonging to the $4^{\text {th }}$ or $5^{\text {th }}$ row. According to this new object, we are considering that these two phalanges belong to the $4^{\text {th }}$ row.

\section{Lower limbs}

Fragment of left femoral diaphysis (Constant collection - Regourdou; fig. 17).

This object is not marked. It comes from faunal material that was kept in a shed on the Regourdou site. Its taphonomic and pathological ravages and its colour fit perfectly with what we know of the paleontological and paleoanthropological collections of the site.

This is a $170 \mathrm{~mm}$-long portion of a diaphysis whose circumference is complete. Being sure of its taxonomic diagnosis, it is easy to lateralize such an object. But, given the faunal assemblage of Regourdou and its characteristics, it was necessary to be cautious. The general morphology of the object, the thickness of the compact bone and the volume of the marrow cavity, certify that this is a human femur. Therefore, it is a distocentral portion of a diaphysis that is sub-circular in section over its entire length. The diameters of the diaphysis are those of a mature bone. 
On the posterior side, we have a slight relief that corresponds to the linea aspera. Depending on the morphology of this linea, of its curvature, of its development and its position relative to the other sides of the diaphysis, we are certainly in the presence of a left femoral diaphysis fragment. We find confirmation of this lateralization with the shape of the section of the diaphysis at the level of the proximal extremity that shows a marked bone strengthening that corresponds to middle fibers often described in Neanderthals (McCown and Keith 1939; Suzuki and Takai 1970; Trinkaus 1976).

Its distal extremity has a very fine and well-structured cancellous bone lining the circumference of the compact bone several $\mathrm{mm}$ thick (the maximum development being at the level of the lateral side of the medullary cavity). At the proximal end, the medullary cavity is partially filled by looser cancellous bone with a maximum development at the level of the lateral and posterior face. The presence of the same type of cancellous bone can be noted on the proximal fragment of the right femur of Regourdou 1 at the level of the break that affects the middle of the diaphysis. The presence of such a cancellous bone was also observed almost halfway up the diaphysis on an immature femur of a Neanderthal from Cova Negra in Spain (Arsuaga et al. 2007 p. 49).

The shape of the circumference of the diaphysis and the development of the linea aspera are consistent with what we know about Neanderthals femora, but this diaphyseal fragment shows no curvature, whether mediolateral or anteroposterior, which is quite pronounced among Neanderthals. The mediolateral curvature is also reduced on the right femur of Regourdou 1.

This fragment of left femur has several differences with the right one we found in 2008 that we associated with the individual No. 1 . The diaphysis is significantly less curved and more circular (especially proximally). The linea aspera is more pronounced. Middiaphysis, both femora have fairly similar diameters and a similar robustness.

The presence of two bony prominences is noted; they most probably correspond to calcified subperiosteal hematomas (Aufderheide et al. 1998). They are located on the medial edge, partly on the anterior face for the largest and lowest one and under the proximal extremity for the second one. Three prominences, probably from the same cause, are visible on the diaphysis of the right femur.

Similarly, both diaphysis fragments bear numerous post-depositional traces affecting the compact bone. Some are probably due to gnawing.

Finally, we know that Regourdou 1 shows a significant asymmetry of the upper limbs (Volpato et al. 2012), a distinct asymmetry of the articular facets on its sacrum (Meyer et al. 2011) and a certain asymmetry of the superior articular facets of the T2 (GómezOlivencia et al. 2013b). Consequently we will need to test whether the femoral asymmetry that we observed between these two bones fits within the variability of a sample of recent individuals with the same type of differences in the pelvis.

Distal extremity of right tibia (NMP collection; fig. 18). Its marking, G3-11, certifies that it was unearthed during the excavations directed by E. Bonifay. The distal articular facet is missing, the extremity of the diaphysis having many fresh breaks. Its resemblance to the left tibia fragment isolated in 2008 allows us to assign it to Regourdou 1.

Distal extremity of right fibula (MAAP collection; fig. 19). This bone is marked "Reg. 1957 Sep." It corresponds to the distal articular extremity, very well preserved. The break at 
the base of the diaphysis is fresh. The distal extremity seems wide in relation to its height. The lateral malleolus notch appears well marked.

71 Left calcaneus (NMP collection - Regourdou; Fig. 20). This bone is badly preserved. It has significant recent gaps (fresh fractures) on its faces: (i) the lateral one is almost completely eroded, as the peroneal tubercle is absent, (ii) the medial one where the sustentaculum tali is destroyed as well as the anterior articular facet with the talus and (iii) the dorsal one where the top of the articular facet with the talus, the articular facet with the cuboid and the trochlear process are missing. On these eroded areas, we can see the structure of the cancellous bone.

It is not labeled or the marking disappeared following the erosion of the bone. On the plantar side, the medial process is particularly protruding downward and forward.

Given numerous morphometric similarities, this calcaneus corresponds, according to us, to the symmetrical of the right one associated to Regourdou 1. As the right calcaneus and the right and left talus were unearthed near the area (e.g. square G2; Maureille et al. 2014 - unpublished) that yielded other human remains representing Regourdou 1, it is reasonable to assume that this new left calcaneus also belongs to this specimen. We believe that the articular asymmetry observed between the right calcaneus and talus by Trinkaus (1975) could be partly the result, on the first bone, of a deformation (perhaps post-mortem, this will need to be checked) of the posterior articular facet for the talus. Finally, the articular congruence between the left calcaneus and talus seems better.

74 Naturally, then, the other right calcaneus (see below) then represents an additional individual: Regourdou 2.

Figure 11 - Sixteen ribs fragments for which their diagnosis as human remains uncertain.

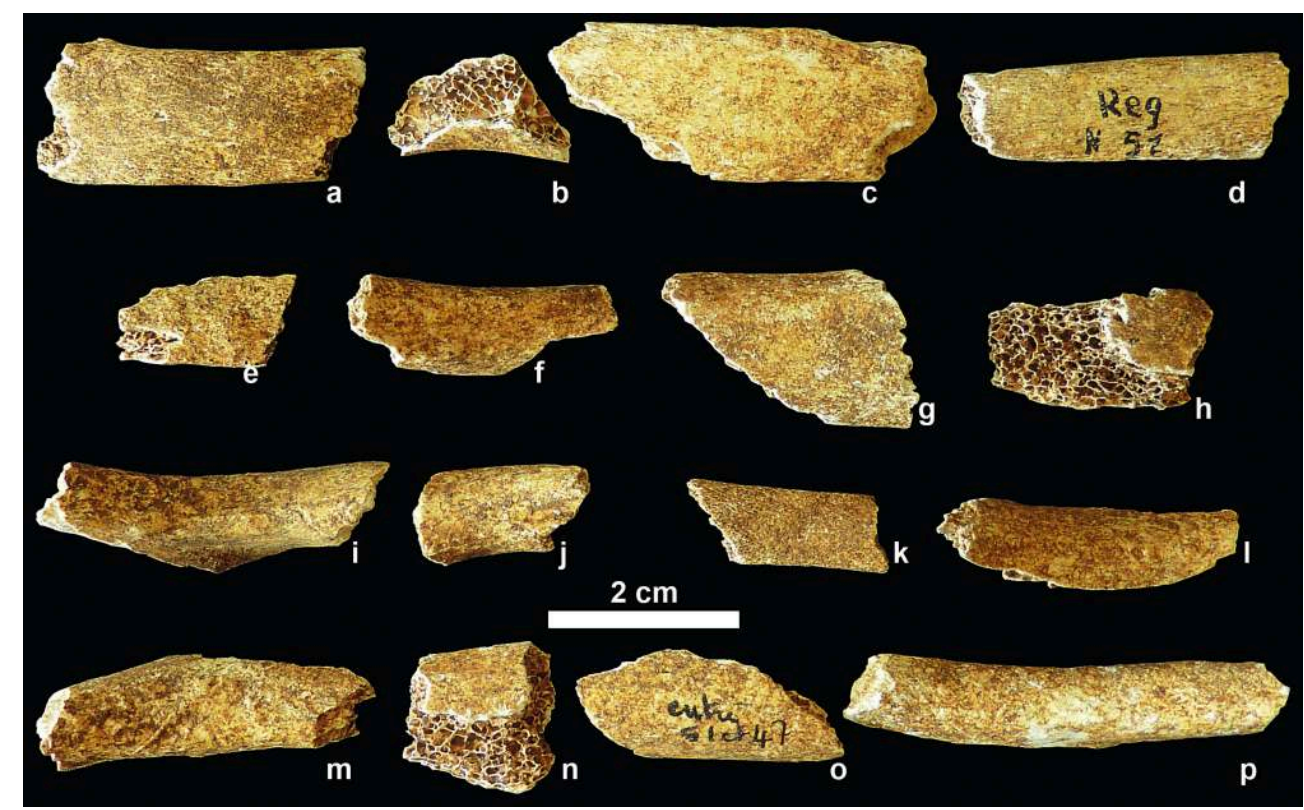


Figure 12 - New mesosternal fragment (on the left) and (on the right) said fragment shown refitted onto the previously- known mesosternal segments of Regourdou 1.

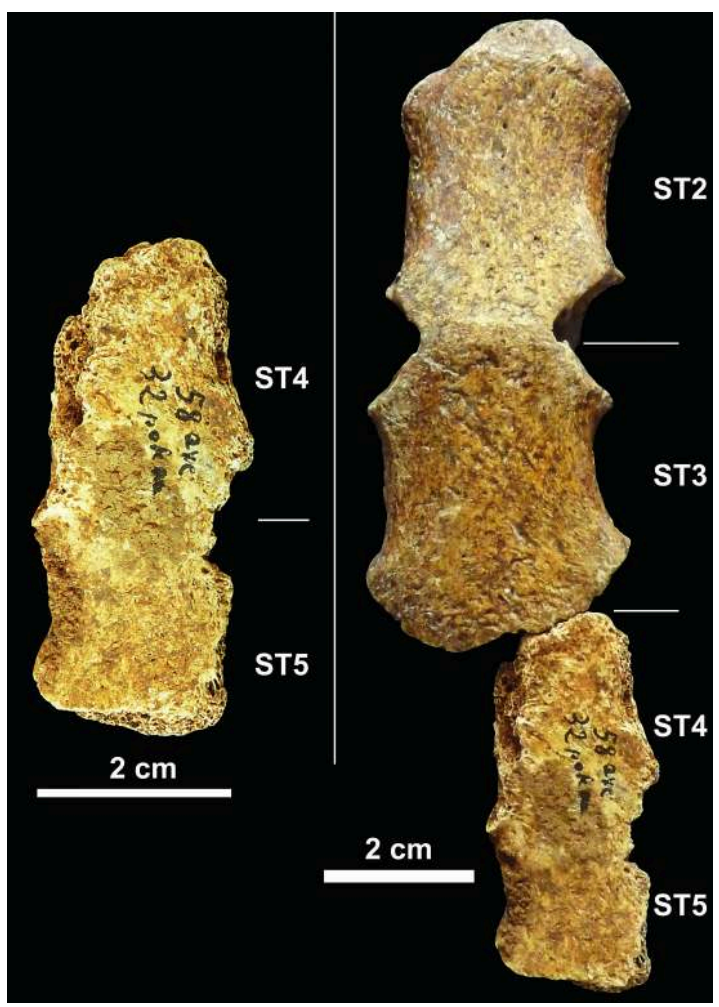

Figure 13 - Coracoid process of the left scapula; $a=$ posterior view; $b=$ inferior view.

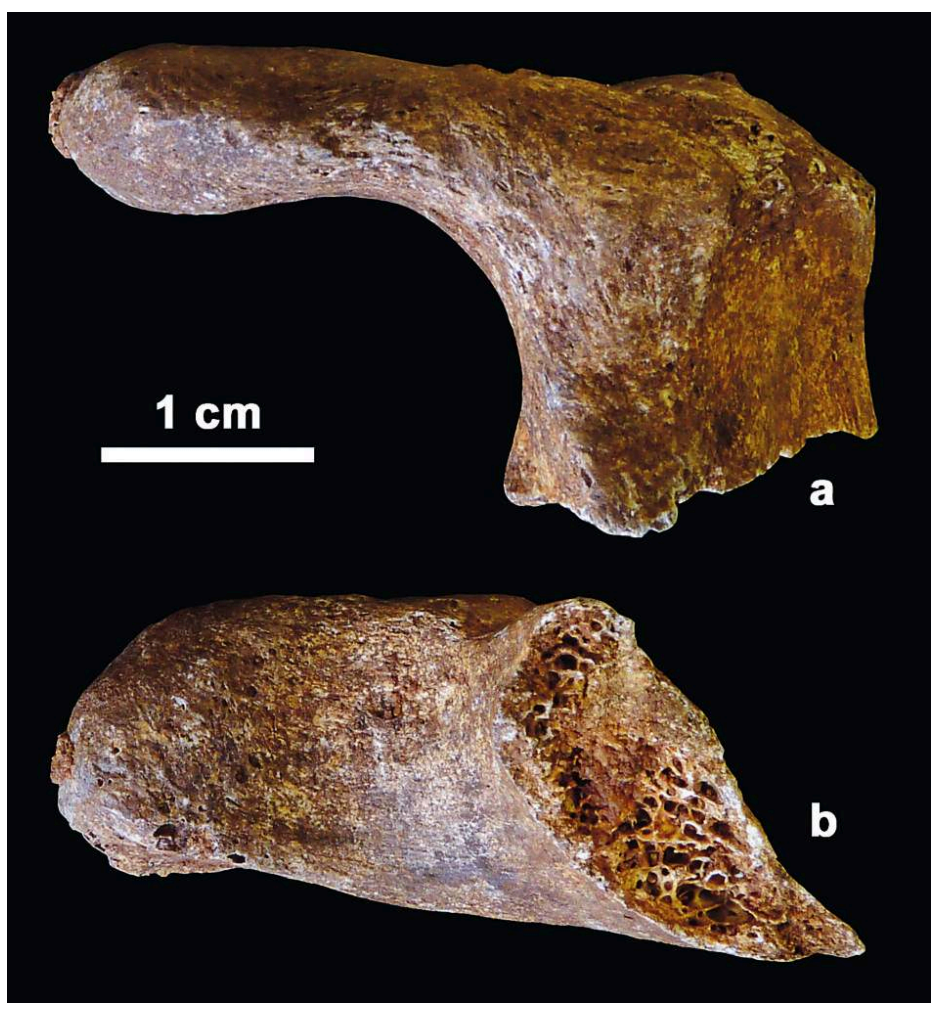


Figure 14 - Fragment of distal end of the left ulna (a), compared to the same part of the previouslyknown right ulna (b) of Regourdou 1.

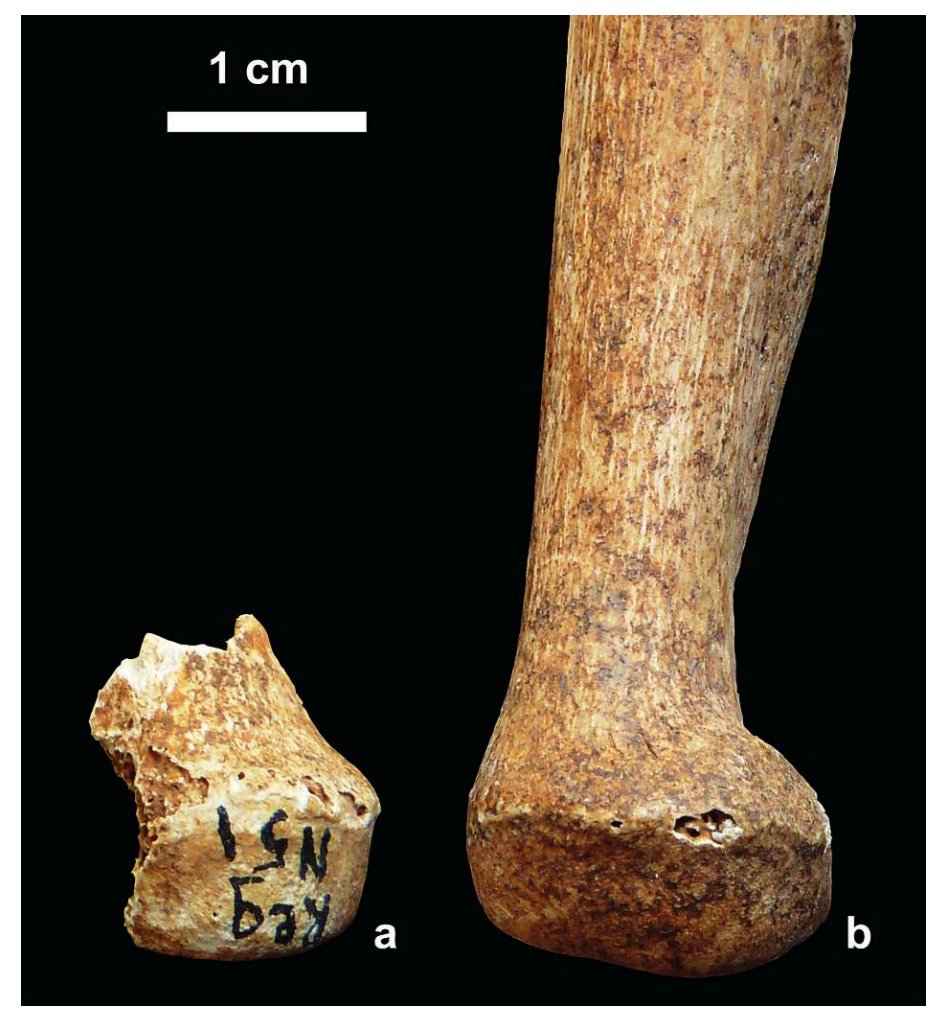

\section{2 - Other data on the skeletal remains of Regourdou 1}

\section{Bones damaged or missing after having been studied by J. Piveteau $(1963,1964,1966)$}

Axis. The partial destruction of the bone is related to a moulding activity (M. Chech, pers. comm.) as elastomers are still present in the cancellous tissue. The left transverse lamina and the spinous process visible in the original description of Piveteau (1966) are missing (Gomez-Olivencia et al. 2013b).

Fourth cervical vertebra. A portion of the neural arch (left articular facets and left lamina) present in the original description of Piveteau (1966) is now missing as well as the right lateral process (Gomez-Olivencia et al. 2013b).

77 Fifth cervical vertebra. A portion of the neural arch (articular facets), the lateral process and a small lamina part (Piveteau 1966) are now lacking (Gómez-Olivencia et al. 2013b). Carpal bone. The right capitate has been studied and drawn in Perigueux in February 1985 by H. Duday. This bone seemed complete. Currently, it is no longer in the paleoanthropological collection.

Right calcaneus "Regourdou G3 63." It is noted that the surface of the dorsal extremity of the sustentaculum tali is eroded and that elastomers are still present in the cancellous tissue.

80 In addition, two bone samples were taken on two long bones. The first one, nearly $1 \mathrm{~cm}^{3}$ in volume, is located over the entire width of the posterior face of the distal half of the 
left humerus, just below the fresh break. It was done for palaeogenetic analyses by the Department of Evolutionary Genetics of the Max Planck Institute for Evolutionary Anthropology in Leipzig on December 4,2006 . The second one, equally large ( $2 \mathrm{~cm}$ long, $0.5 \mathrm{~cm}$ wide), was done in September 2012 by the Senckenberg Center for Human Evolution and Palaeoenvironment of the University of Tübingen for palaeo-isotopic analyses. It is located on the distal half of the left femoral diaphysis, again at the level of the fresh break, and on the posteromedial face of the bone.

\section{New attribution}

$817^{\text {th }}$ cervical vertebra. We considered that the first thoracic vertebra described by Piveteau (1966 - p. 191) is actually the $7^{\text {th }}$ cervical vertebra now better preserved following the discovery of the spinous process (V\#al, see above; Gómez-Olivencia et al. 2013b, tab. 1). Indeed, the potential presence of incomplete transverse foramen and the absence of large articular facet for the first rib are characteristic of this cervical vertebra. In addition, the articulation with the second thoracic vertebra (whose number is known with certainty because of the superior articular half facet with the first rib) is not good. $2^{\text {nd }}$ thoracic vertebra. The fourth thoracic vertebra described by Piveteau (1966 - p. 193) is in fact the second of that part of the rachis. Indeed, its body is anteroposteriorly quite small with a rather rectangular shape when a $4^{\text {th }}$ vertebra should have a body with a more quadrangular shape. The orientation of the transverse processes is more perpendicular to the median plane of the bone than on a $3^{\text {rd }}$ or $4^{\text {th }}$ thoracic vertebra. Finally, it has a superior articular half facet for the head of the second rib, and therefore we can also exclude that it is a first thoracic vertebra (which should have a complete costal articular facet). 
Figure 15 - Left lunate (a \& b), left capitulum (c \& d), right trapezium (e) compared to the previouslyknown left trapezium (f) of Regourdou 1.

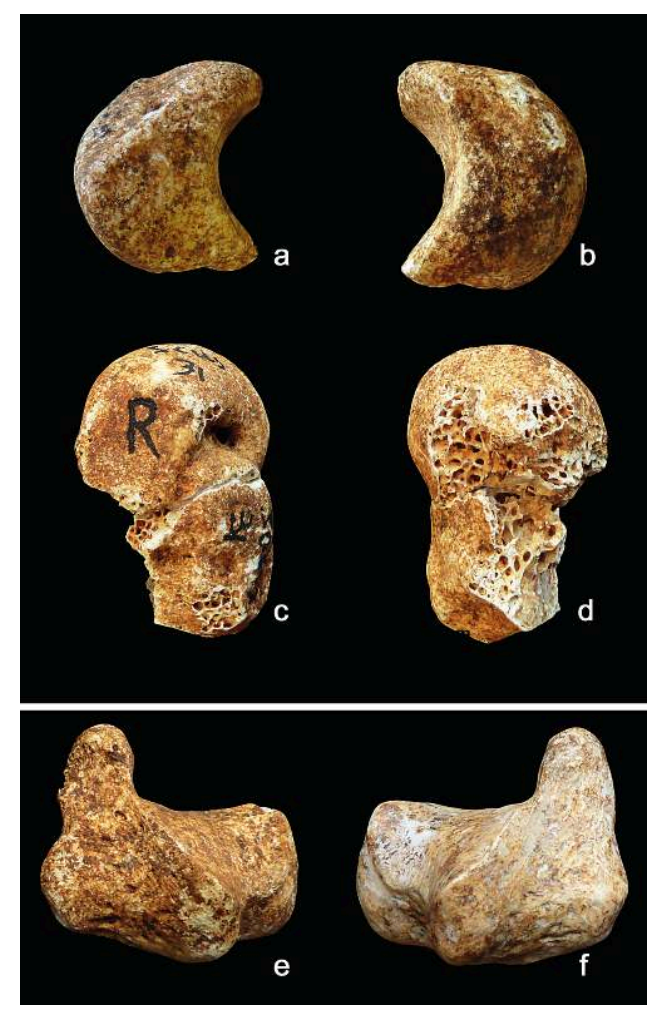


Figure 16 - Left middle phalanx (4th or 5th ray, $a=$ dorsal view, $c=$ palmar view), compared to its antimere (b \& c); distal three-quarters of the right first metacarpal $(e=$ dorsal view, $g=$ palmar view), compared to its antimere ( $\& \mathrm{~h}$ ); proximal half of right 5 th metacarpal ( $\mathrm{i}=$ dorsal view, $\mathrm{k}=$ palmar view) compared to its antimere (j \& l); proximal end of the left 3rd metacarpal $(m)$ and a view of it refitted onto the previously-known portion of the bone (n).

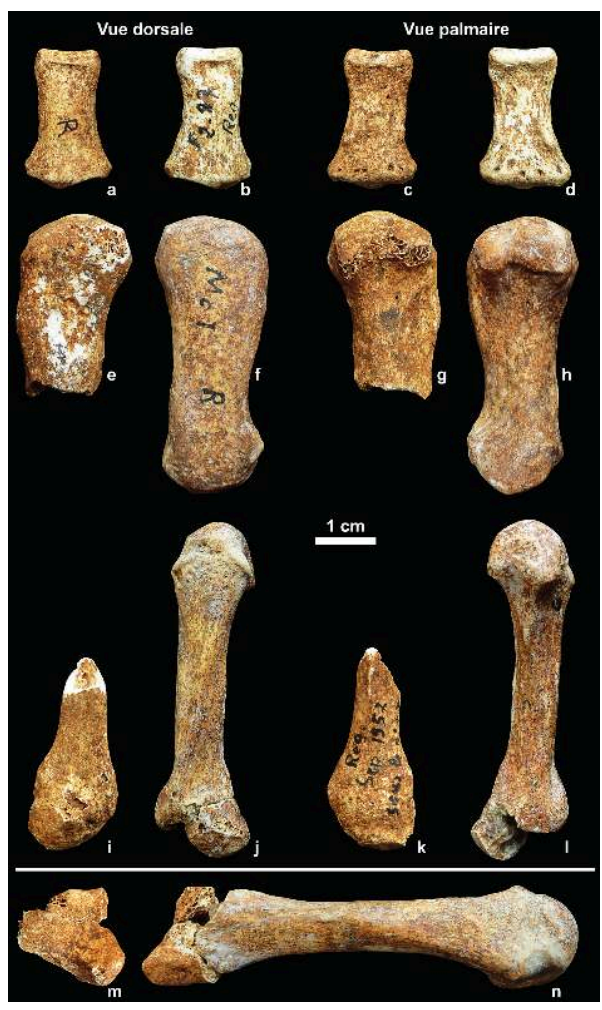

\section{The second individual: Regourdou 2}

To date, the presence of a new calcaneus certifies the existence of a second individual. This is an unmarked right bone without precise information on its location within the site (fig. 21). According to a communication of E. Bonifay, it would have come from a breccia zone excavated in the NE of the site, perhaps in 1963, which may correspond to squares K8, K9, L9 and L8, therefore far from the human deposit and at a certain distance from the area that yielded the remains of Regourdou 1. This object was given to B. Vandermeersch by E. Bonifay. B. Vandermeersch then entrusted it to one of us (ChC).

The calcaneus is still unpublished although one study mentions its existence (Schmitt 1998). In another work (Raichlen et al. 2011), the measurements, taken in previous publications, of the calcaneus identified as Regourdou 2 correspond, in fact, to the average measurements of Regourdou 1 and Regourdou 2.

This bone is concreted and overall well-preserved, even if the outer surface of the bone is often eroded, exposing the cancellous bone. At the lateral face, a large piece of the bone is missing at the base and in front of the tuberosity of the calcaneus. Thus the lateral process is totally absent. The medial face shows a deep straight slit at the dorsal side slightly below the posterior articular surface with the talus. elongation of the body, developed muscular insertions, extended areas of articular 
facets (posterior and cuboid). Regarding the inter-individual variability, it shows great length (connected to an elongated body), a significant height and an average width. Thus, its proportions put it apart from the other Neanderthal calcaneus (Coutinho Nogueira 2013 - unpublished).

From this work, the dimensions of this new right calcaneus are different from those of the other two associated to Regourdou 1.

\section{A tibia fragment "modern" in morphology}

The collection of the site museum of Regourdou also yielded a human tibia represented by the proximal two-thirds of the bone (fig. 22). Unfortunately, it is not marked. The missing part of the bone corresponds to a recent break as well as an elongated removal, several centimetres long, on the anterior side on the tibial crest. This object was isolated from a rack containing recent bovine bones. However, it has a patina that makes it look very old but very different from that of the other bone remains of the two individuals of Regourdou.

By all its morphological characteristics, this tibia, with well pronounced muscle insertion crests, falls within the variability of anatomically modern humans (Vandermeersch 1981). Therefore, we believe it does not show any of the frequent characteristics of Neanderthals (Trinkaus 1983). Finally, we note at the broken extremity of the diaphysis, a cortical bone that seems thick and, above all, an almost non-existent medullary cavity (at this level) as it is filled by rather dense cancellous bone. The frequency of this type of partial filling of the marrow cavity with cancellous bone in humans has not been the subject of much research. Logically, we associate it with intense hematopoietic activity.

Unfortunately, no data allow us to know if this tibia fragment comes from the Regourdou deposit. Moreover, given the conditions (much varied) of the accumulation of the Regourdou Site Museum collection and the diverse origins of some objects, it is impossible - without absolute dating - to specify the scientific interest of this bone. But one should remember that R. Constant stated in the newspaper Le Populaire du Centre (20 May 1958) that he discovered, before unearthing the remains of Regourdou 1, " $a$ human femur, several vertebrae and a tibia" and lithic remains he qualifies as belonging to "a microlithic industry." Bonifay (1964, p. 61) mentions the existence of "some traces of upper Palaeolithic (Aurignacian?)" in layer S corresponding to the accumulation of red sand in a depression linked to the collapse of the ceiling of the cave. 
Figure 17 - Diaphyseal fragment of the left femur. Proximal end is up. Left is posterior view; right is anterior view.

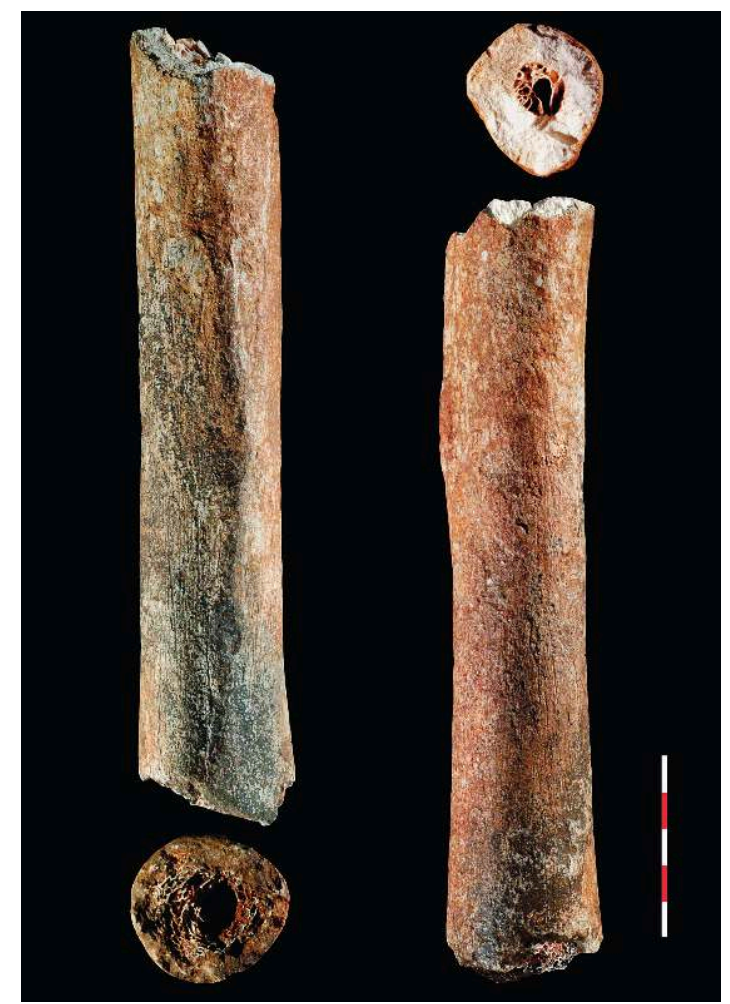

Figure 18 - Fragment of distal end of the right tibia. Left to right: anterior view, lateral view, posterior view.

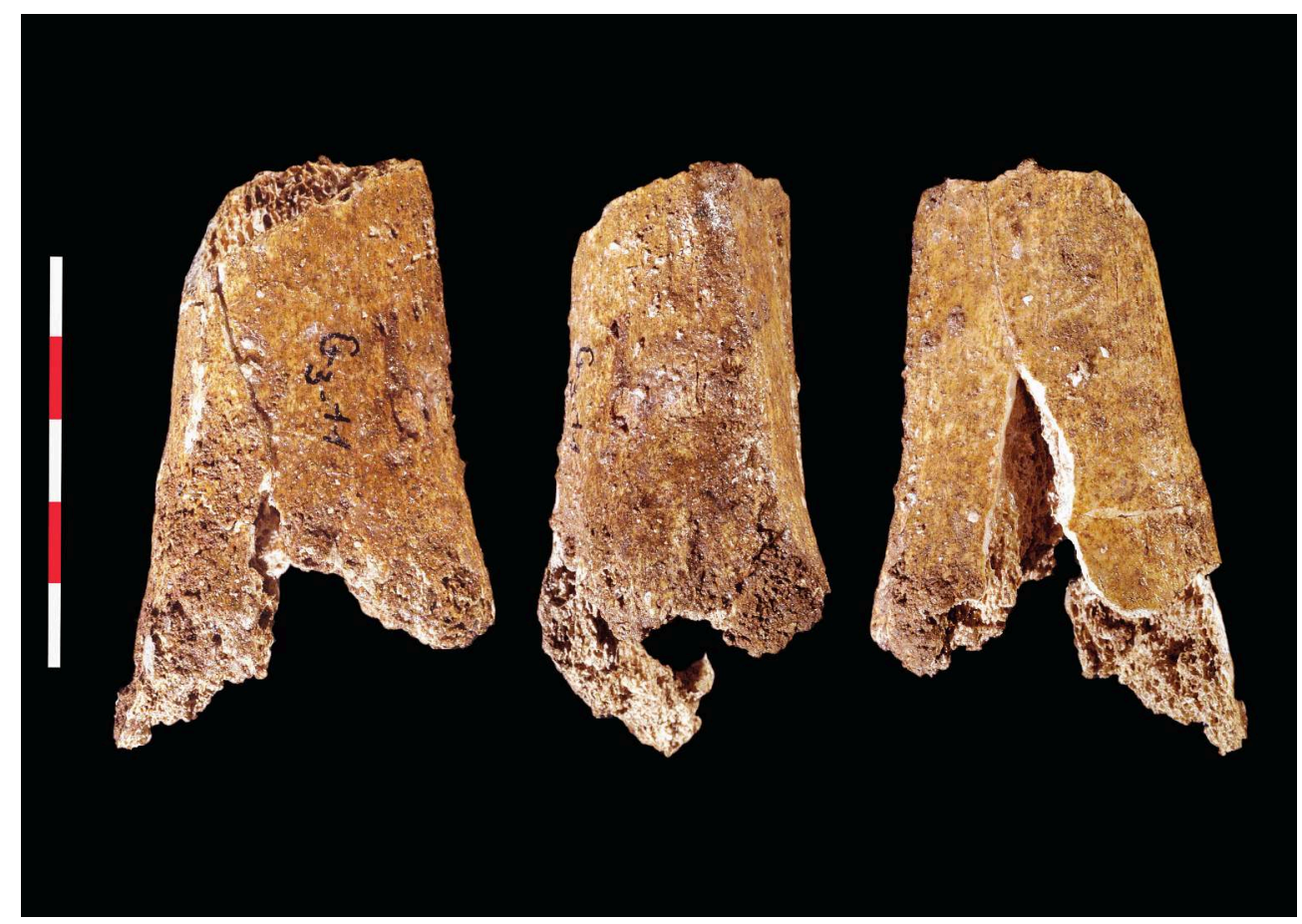


Figure 19 - Distal end of the right fibula, $a=$ lateral view; $b=$ medial view.

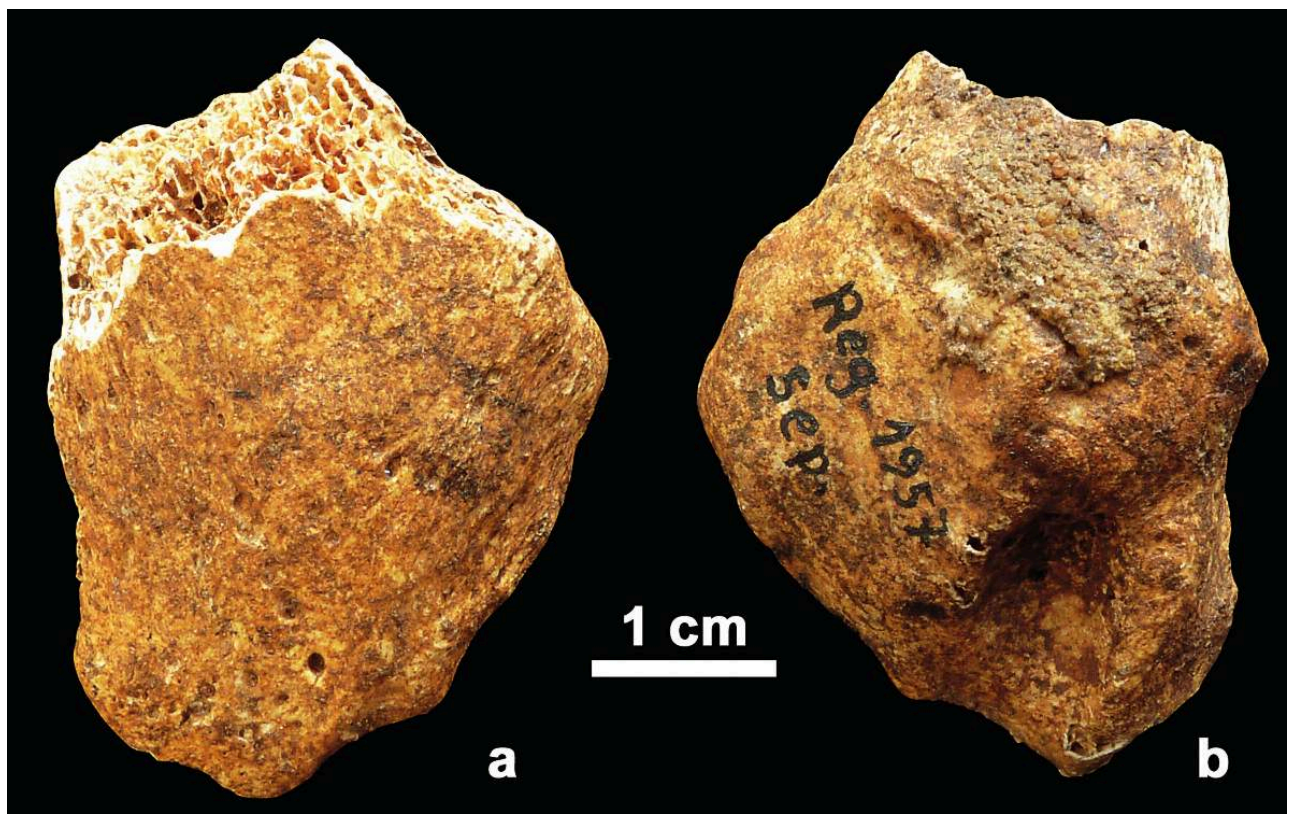




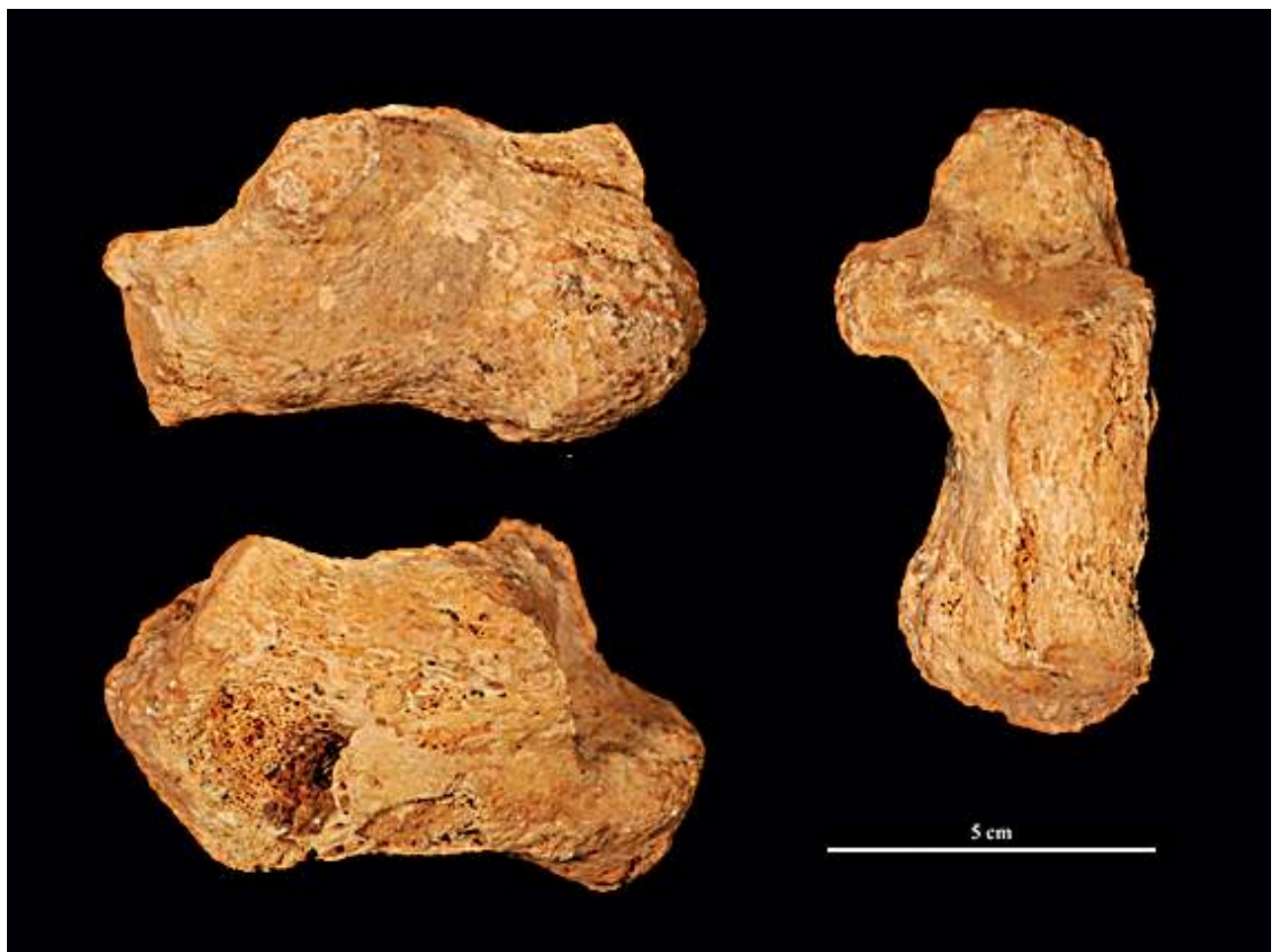

Figure 20 - Left calcaneus of Regourdou 1 (on the left) compared to the right (on the right). Dorsal view above; medial view below.

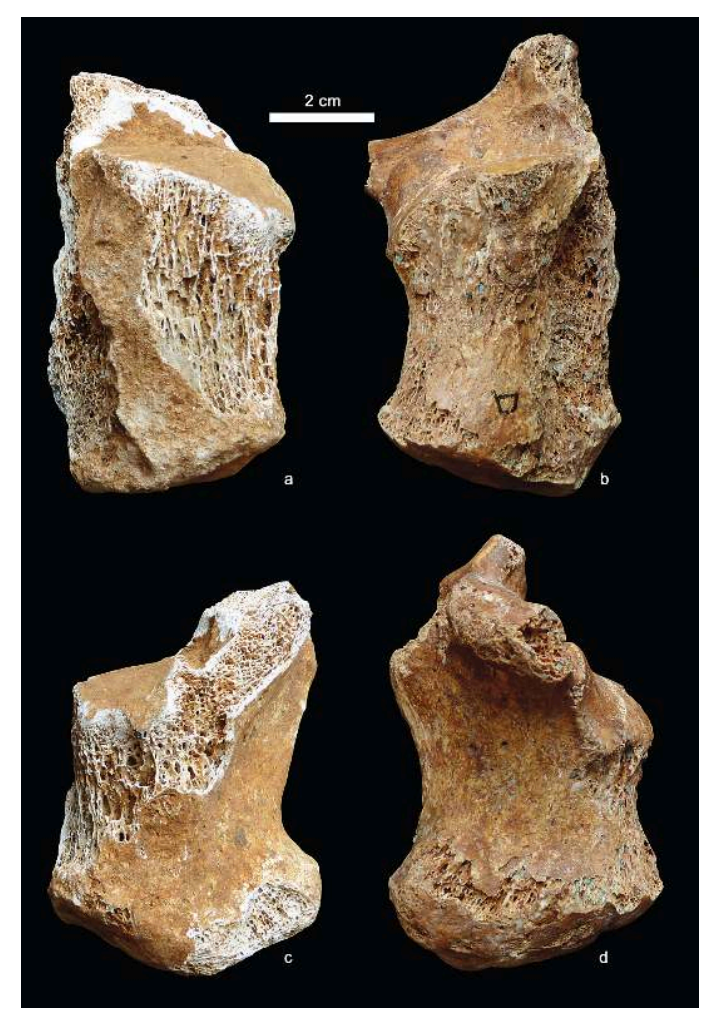


Figure 21 - The new right calcaneus attributed to Regourdou 2. Medial view above; lateral view below; dorsal view on the right.

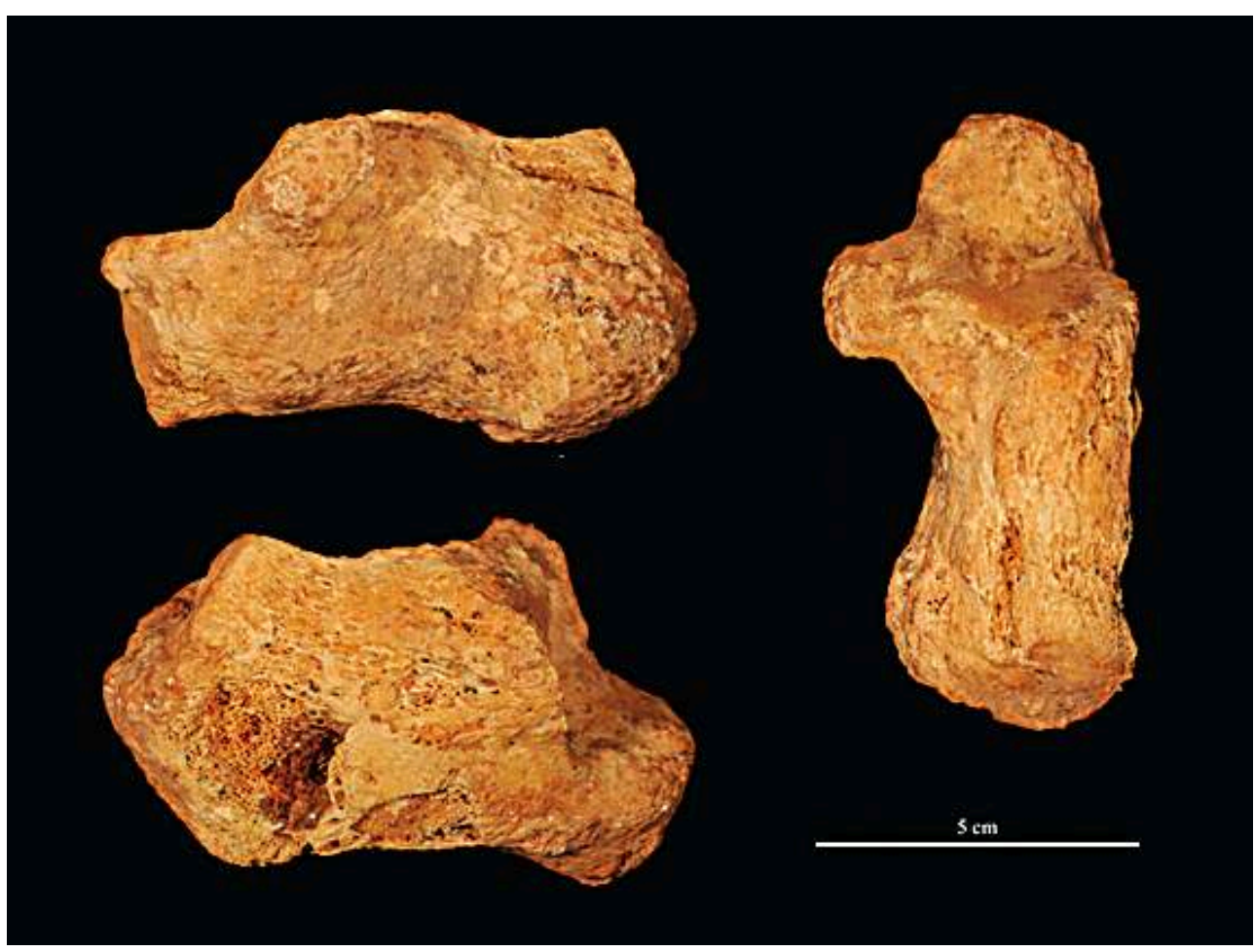

Figure 22 - The anatomically modern right tibia, from left to right: anterior view, lateral view, posterior view, medial view.

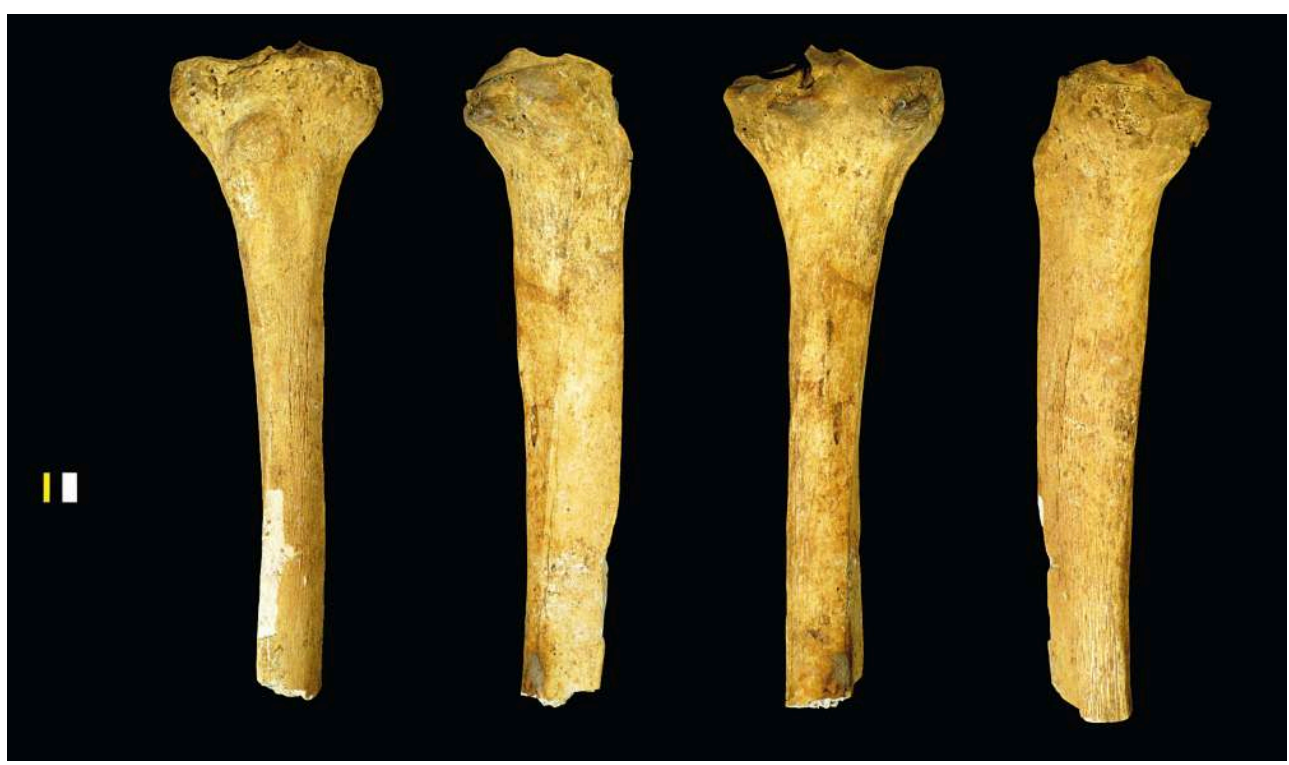

\section{Conclusions}

91 Fifty-nine new human remains could be attributed to Regourdou 1 . They are essentially fragments belonging to the axial skeleton $(n=46)$, the upper $(n=9)$ and lower $(n=4)$ limbs. Their current state of preservation is often the result of the highly destructive conditions of the discovery, but it is regrettable to note that, since their exhumation, 
several bones also suffered from their post- excavation history. Fortunately, they complement much the Regourdou 1 skeleton, for example for an anatomical part - the axial skeleton - that was already fairly well represented.

These new fragments thus allowed several pairings (the discovery of a left calcaneus allows us to assume that the right one and the two tali belong to Regourdou 1) and several refitting (at the vertebrae, the ribs with for example the second left rib and the eleventh right rib (marked "Reg 1957 sepult 51" and " Regourdou Sep 195758 par \% axe 32 du poteau") that are now almost complete). Regourdou 1 becomes one of the betterpreserved Neanderthals for the infra-cranial skeleton (Couture 2008) but the skull is still lacking. Despite a very careful examination of the entire collection of faunal or human remains from Regourdou, we still have not isolated any skull fragment or any isolated tooth of the upper jaw.

On none of these objects, except the left femoral diaphysis, can we identify damage allowing us to discuss the taphonomic evolution of Regourdou 1 at the site. Note that the presence of a portion of the atlas invalidates the hypothesis we proposed (Madelaine et al. 2008) that this vertebra of Regourdou 1 could have accompanied the skull.

Finally, the presence of another right calcaneus certifies the existence in the deposit of at least two Neanderthal adult individuals. Regourdou 1, a young adult, is known by a sub-complete skeleton with a very well represented infra-cranial part. We are associating it to the pair of tali and the symmetrical calcaneus. He is argued to have been a small-sized Neanderthal (Plavcan et al. 2014). Regourdou 2, another adult known by a right calcaneus, would most likely have been taller than he.

A potential third specimen represented by a right tibia, morphologically modern, could come from the site. Unfortunately, there is no evidence to validate this. Only a direct absolute dating of this bone will specify its paleoanthropological interest.

\section{BIBLIOGRAPHY}

ARSUAGA J.L., VILLAVERDE V., QUAM R., MARTÍNEZ I., CARRETERO J.M., LORENZO C. et GRACIA

A. 2007 - New Neandertal remains from Cova Negra (Valencia, Spain). Journal of Human Evolution, 52, p. 31-58.

AUFDERHEIDE A.C. et RODRIGUEZ-MARTIN C. 1998 - The Cambridge encyclopedia of human paleopathology. Cambridge : Cambridge University Press, 478 p.

BONIFAY E. 1964 - La grotte de Régourdou (Montignac, Dordogne). Stratigraphie et industrie lithique moustérienne. L'Anthropologie, 68, p. 49-64.

BONIFAY E. 1965 - Un ensemble rituel moustérien à la grotte du Régourdou (Montignac, Dordogne). In : Actes du VIèmè Congrès International des Sciences Préhistoriques et Protohistoriques, Session I-IV. Rome, p. 136-140. 
BONIFAY E. 2002 - L'Homme de Néandertal et l'ours (Ursus arctos) dans la grotte du Régourdou (Montignac-sur-Vézère, Dordogne, France). In : T. Tillet, L.R. Binford (Ed.), L'Ours et l'Homme. Actes du Colloque d'Auberivesen-Royans (1997). Liège, ERAUL, p. 247-254.

BONIFAY E., VANDERMEERSCH B. 1962 - Dépôts rituels d'ossements d'ours dans le gisement moustérien du Régourdou (Montignac, Dordogne). Comptes Rendus de l'Académie des Sciences de Paris, 255, p. 1635-1636.

BONIFAY E., VANDERMEERSCH B., COUTURE C. et PANATTONI R. 2007 - La sépulture néandertalienne du Régourdou (Montignac-sur-Vezère, Dordogne). Mercuès : Documents du Centre d'Etude et de Recherche sur les Lacs, Anciens lacs et Tourbières du Massif-Central, 18 p.

COUTINHO-NOGUEIRA D. 2013 - inédit - Le calcaneus inédit de Regourdou 2 : description morphométrique et sa position dans la variabilité néandertalienne. Mémoire de recherche de Master 2, spécialité Anthropologie biologique, Université Bordeaux 1, 67 p.

COUTURE C. 2008 - Les caractères anatomiques du squelette néandertalien Régourdou 1. Bull. de la Société d'Etudes et de Recherches Préhistoriques des Eyzies, 57, p. 32-40, 4 fig.

FRANCISCUS R. G. 1989 - Neandertal mesosterna and noses: implications for activity and biogeographical patterning. American Journal of Physical Anthropology, abstracts, 78, p. 223.

FRANCISCUS R.G., CHURCHILL S.E. 2002 - The costal skeleton of Shanidar 3 and a reappraisal of Neandertal thoracic morphology. Journal of Human Evolution, 42, p. 303-356.

GÓMEZ-OLIVENCIA A., FRANCISCUS R.G., COUTURE-VESCHAMBRE C, MAUREILLE B. et ARSUAGA J. L. 2012 - The mesosternum of the Regourdou 1 Neandertal revisited. Journal of Human Evolution, 62, 4: 511-519.

GÓMEZ-OLIVENCIA A., BEEN E., ARSUAGA J.L. et STOCK J.T. 2013a - The Neandertal vertebral column 1: The cervical spine. Journal of Human Evolution, 64: 608-630.

GÓMEZ-OLIVENCIA A., COUTURE-VESCHAMBRE C., MADELAINE S., MAUREILLE B. 2013b - The vertebral column of the Regourdou 1 Neandertal. Journal of Human Evolution, 64, p. 582-607.

MADELAINE S., MAUREILLE B., CAVANHIÉ N., COUTURE-VESCHAMBRE C., BONIFAY E., ARMAND D., BONIFAY M.-F., DUDAY H., FOSSE P. et VANDERMEERSCH B. 2008 - Nouveaux restes humains moustériens rapportés au squelette néandertalien de Regourdou 1 (Regourdou, commune de Montignac, Dordogne, France). Paleo, 20, p. 101-114.

MAUREILLE B. (dir.), HOLLIDAY T., LACRAMPE-CUYAUBÈRE F., LAHAYE C., LEBRUN B., LE GUET E., MADELAINE S., MUTH X., PELLETIER M., ROYER A., TEXIER J.-P. et TURQ A. 2014 - inédit - Le Regourdou (commune de Montignac, Dordogne), rapport de fouilles programmées annuelles (2014) et demande d'autorisation de fouilles programmées annuelle 2015. Programme P3, Ministère de la Culture et la Communication, $193 \mathrm{p}$.

McCOWN T.D. et KEITH A. 1939 - The Stone Age of Mount Carmel, vol. 2. The Fossil Human Remains from the Levalloisio-Mousterian. Oxford: Clarendon Press, $390 \mathrm{p}$.

MEYER V., BRUZEK J., COUTURE-VESCHAMBRE C., MADELAINE S. et MAUREILLE B. 2011 - Un nouveau bassin néandertalien : description morphologique des restes pelviens de Regourdou 1 (Montignac, Dordogne, France). Paleo, 22, p. 207-222.

MUSGRAVE J.H. 1971 - How dexterous was Neandertal man? Nature, 233, p. 538-541.

NIEWOEHNER W.A. 2000 - The functional anatomy of Late Pleistocene and recent human carpometacarpal and metacarpophalangeal articulations. Université du Nouveau Mexique, 2000. 485 p. Thèse de doctorat. 
PIVETEAU J. 1959 - Les restes humains de la grotte de Regourdou (Dordogne). Comptes Rendus de l'Académie des Sciences de Paris, sér. D, 248, p. 40-44.

PIVETEAU J. 1963 - La grotte de Regourdou (Dordogne). Paléontologie humaine. Annales de Paléontologie, XLIX, p. 285-304.

PIVETEAU J. 1964 - La grotte de Regourdou (Dordogne). Paléontologie humaine. Annales de Paléontologie (Vertébrés), L, p. 155-194.

PIVETEAU J. 1966 - La grotte de Regourdou (Dordogne). Paléontologie humaine. Annales de Paléontologie (Vertébrés), LII, p. 163-194.

PLAVCAN J. M., MEYER V., HAMMONDC A.S., COUTURE-VESCHAMBRE C., MADELAINE S., HOLLIDAY T.W., MAUREILLE B., WARD C. V. et TRINKAUS E. 1976 - The Regourdou 1 Neandertal body size. C. R. Palévol, 13, p. 747-754.

RAICHLEN D.A., ARMSTRONG H. et LIEBERMAN D.E. 2011 - Calcaneus length determines running economy: Implications for endurance running performance in modern humans and Neandertals. Journal of Human Evolution, 60, 3, p. 299-308.

SCHMITT A. 1998 - Approche de la variablité du calcaneus néandertalien. Comparaison avec l'Homme moderne. Bulletins et Mémoires de la Société d'anthropologie de Paris, Nouvelle Série, 10, fascicule 3-4, p. 273-292.

SUZUKI H. et TAKAÏ F. 1970 - The Amud man and his cave site. Tokyo: Academic Press of Japan, $530 \mathrm{p}$.

TRINKAUS E. 1975 - A functional analysis of the Neandertal foot. Philadelphia: University of Pennsylvania, $465 \mathrm{p}$.

TRINKAUS E. 1976 - The evolution of the hominid femoral diaphysis during the Upper Pleistocene in Europe and the Near East. Zeitschrift für Morphologie und Anthropologie, 67, p. 291-319.

VALLOIS H.-V. 1965 - Le sternum néandertalien du Regourdou. Anthropologische Anzeitung, 29, p. 273-289.

VALLOIS H.-V. et DE FÉLICE S. 1976 - Le sternum néandertalien du Regourdou. Note complémentaire. Anthropologische Anzeitung, 35, p. 229-235.

VANDERMEERSCH B. 1981 - Les Hommes fossiles de Qafzeh (Israël). Cahiers de Paléontologie. Paris : éds. du C.N.R.S., 319 p.

VANDERMEERSCH B. 1991 - La ceinture scapulaire et les membres supérieurs. In : O. Bar-Yosef, B. Vandermeersch (Ed.), Le squelette moustérien de Kébara 2. Cahiers de Paléoanthropologie. Paris: éditions du CNRS, p. 157-178.

VANDERMEERSCH B. et TRINKAUS E. 1995 - The postcranial remains of the Régourdou 1 Neandertal: the shoulder and arm remains. Journal of Human Evolution, 29, p. 439-476.

VILLENA Y MOTA N. 1997 - inédit - Hiérarchie et fiabilité des liaisons ostéologiques (par symétrie et par contiguité articulaire) dans l'étude des sépultures anciennes. Talence : Université Bordeaux I, 1997. $317 \mathrm{p}$. Thèse de doctorat.

VOISIN J.-L. 2000 - L'épaule des hominidés. Aspects architecturaux et fonctionnels, références particulières à la clavicule. Paris: Museum national d'histoire naturelle, 2000. $429 \mathrm{p}$. Thèse de doctorat. 
VOLPATO V., MACCHIARELLI R., GUATELLI-STEINBERG D., FIORE I., BONDIOLI L. et FRAYER D.W. 2012 - Hand to Mouth in a Neandertal: Right-Handedness in Regourdou 1. PloS ONE, 7, e43949.

doi :10.1371/journal.pone.0043949

\section{ABSTRACTS}

In an article published in Paleo number 20 (Madelaine et al. 2008), we announced the discovery of a new series of 11 human remains that we associated with Regourdou individual number 1 (Vandermeersch and Trinkaus 1995), a specimen first brought to light in September 1957. Some of these new bones, in particular the larger ones (femur, tibia, fibula) represent or make more complete skeletal elements that were presumed to have been missing as the result of funerary acts (Bonifay et al. 2007).

In this contribution, we increase the skeletal representation of Regourdou 1 with additional new pieces.

These come in part from the site's faunal collections (property of the Musée national de Préhistoire since 2002), but also from the collections of the Musée d'Art et d'Archéologie de Périgueux. In addition, two pieces: a left femoral diaphysis and the proximal half of a tibia come from the collection of the Constant family, but the morphology of the latter does not appear to be that of a Neandertal.

These new discoveries increase our knowledge of Neandertal anatomical variability and the history of the site's occupation, and also permit us to confirm the presence of at least one second adult Mousterian-associated individual, who is thus far represented solely by a right calcaneus. They also allow us to revisit an interesting hypothesis regarding the taphonomic history of the most complete individual from the site (Regourdou 1), a hypothesis we put forth in 2008 that now turns out to be false. Finally, the origin of the individual represented by the tibia (which evinces modern morphology) is unknown. We will therefore need to obtain an absolute direct date on it.

Dans un article publié dans le $n^{\circ} 20$ de la revue Paleo (Madelaine et al. 2008) nous avons annoncé la découverte d'une série de 11 nouveaux restes humains que nous avons pu rapporter à l'individu $\mathrm{n}^{\circ} 1$ (Vandermeersch et Trinkaus 1995) de Regourdou mis au jour en septembre 1957. Certains, parmi les plus conséquents (fémur, tibia, fibula), représentaient ou complétaient des régions squelettiques supposées manquantes en raison de gestes funéraires (Bonifay et al. 2007).

Dans cette contribution, nous augmentons la représentation squelettique de Regourdou 1 avec de nouvelles pièces. Elles proviennent d'une part de la collection de faune (propriété du Musée national de Préhistoire depuis 2002), de celle de la famille constant et d'autre part, des collections du Musée d'Art et d'Archéologie de Périgueux. Deux ossements, une diaphyse fémorale gauche et un tibia, proviennent des collections de faune du Musée de site de Regourdou. Mais la morphologie du second ne permet pas de le rapporter à l'Homme de Néandertal.

Ces nouvelles découvertes nous permettent donc d'enrichir nos connaissances sur la variabilité anatomique néandertalienne et sur l'histoire de l'occupation du site. Elles valident la présence d'au moins un second adulte moustérien, uniquement représenté par un calcaneus droit. Elles nous autorisent aussi à revenir sur une hypothèse intéressant l'histoire taphonomique du sujet le plus complet (Regourdou 1), hypothèse que nous avions avancée en 2008 et qui apparaît désormais fausse. Enfin, l'origine de l'individu représenté par un tibia de morphologie moderne est inconnue. Il nécessitera une tentative de datation absolue directe. 
INDEX

Keywords: Neandertal, Regourdou, Mousterian, Femur, Tibia, Calcaneus, Rib, Vertebra, Metatarsal, Phalanx

Mots-clés: Néandertal, Regourdou, Moustérien, fémur, tibia, calcaneus, côte, vertèbre, métatarse, phalange

\section{AUTHORS}

\section{BRUNO MAUREILLE}

Univ. Bordeaux, CNRS, Ministère de la Culture et de la Communication, PACEA UMR 5199, Allée Geoffroy Saint-Hilaire, FR-33615 Pessac - b.maureille@pacea.u-bordeaux1.fr

\section{ASIER GÓMEZ-OLIVENCIA}

Dept. Estratigrafía y Paleontología, Facultad de Ciencia y Tecnología, Euskal Herriko Unibertsitatea, UPV-EHU. Apdo. 644, ES-48080 Bilbao ; IKERBASQUE. Basque Foundation for Science ; Équipe de Paléontologie Humaine, UMR 7194, CNRS, Département de Préhistoire, Muséum national d'Histoire naturelle, Musée de l'Homme, 17 Place du Trocadéro, FR-75016 Paris ; Centro UCM-ISCIII de Investigación sobre Evolución y Comportamiento Humanos, Avda. Monforte de Lemos 5 (Pabellón 14), ES-28029 Madrid - asier.gomezo@ehu.eus

\section{CHRISTINE COUTURE-VESCHAMBRE}

Univ. Bordeaux, CNRS, Ministère de la Culture et de la Communication, PACEA UMR 5199, Allée Geoffroy Saint-Hilaire, FR-33615 Pessac

\section{STÉPHANE MADELAINE}

Musée national de Préhistoire, 1 rue du Musée, FR-24620 Les Eyzies-de-Tayac stephane.madelaine@culture.gouv.fr Univ. Bordeaux, CNRS, Ministère de la Culture et de la Communication, PACEA UMR 5199, Allée Geoffroy Saint-Hilaire, FR-33615 Pessac

\section{TRENTON HOLLIDAY}

Department of Anthropology, 101 Dinwiddie Hall, Tulane University, New Orleans, Louisiana 70118 USA; Evolutionary Studies Institute, University of the Witwatersrand, Private Bag 3, Wits 2050, Republic of South Africa - thollid@tulane.edu 